\title{
Understanding the Redox Biology of Selenium in the Search of Targeted Cancer Therapies
}

\author{
Jeffrey M. Stolwijk ${ }^{1, *}$, Rohan Garje ${ }^{2}{ }^{(}$, Jessica C. Sieren ${ }^{3}\left(\mathbb{C}\right.$, Garry R. Buettner ${ }^{1,4}(\mathbb{C}$ and \\ Yousef Zakharia ${ }^{2, *}$ \\ 1 Interdisciplinary Graduate Program in Human Toxicology, The University of Iowa, \\ Iowa City, IA 52242, USA; garry-buettner@uiowa.edu \\ 2 Department of Internal Medicine, Division of Medical Oncology and Hematology, The University of Iowa \\ Hospital and Clinics-Holden Comprehensive Cancer Center, Iowa City, IA 52242, USA; \\ rohan-garje@uiowa.edu \\ 3 Departments of Radiology and Biomedical Engineering, The University of Iowa, Iowa City, IA 52242, USA; \\ jessica-sieren@uiowa.edu \\ 4 Free Radical and Radiation Biology Program, Department of Radiation Oncology, The University of Iowa, \\ Iowa City, IA 52242, USA \\ * Correspondence: jmstolwijk@gmail.com (J.M.S.); yousef-zakharia@uiowa.edu (Y.Z.)
}

Received: 23 March 2020; Accepted: 10 May 2020; Published: 13 May 2020

check for updates

\begin{abstract}
Selenium (Se) is an essential trace nutrient required for optimal human health. It has long been suggested that selenium has anti-cancer properties. However, clinical trials have shown inconclusive results on the potential of Se to prevent cancer. The suggested role of Se in the prevention of cancer is centered around its role as an antioxidant. Recently, the potential of selenium as a drug rather than a supplement has been uncovered. Selenium compounds can generate reactive oxygen species that could enhance the treatment of cancer. Transformed cells have high oxidative distress. As normal cells have a greater capacity to meet oxidative challenges than tumor cells, increasing the flux of oxidants with high dose selenium treatment could result in cancer-specific cell killing. If the availability of Se is limited, supplementation of Se can increase the expression and activities of Se-dependent proteins and enzymes. In cell culture, selenium deficiency is often overlooked. We review the importance of achieving normal selenium biology and how Se deficiency can lead to adverse effects. We examine the vital role of selenium in the prevention and treatment of cancer. Finally, we examine the properties of Se-compounds to better understand how each can be used to address different research questions.
\end{abstract}

Keywords: selenium; selenomethionine; selenoproteins; cancer; glutathione peroxidases; thioredoxin reductases

\section{Introduction}

Selenium (Se) is a trace element, essential for optimal health. In the mid 20th century selenium was found to be protective in liver tissue [1-3]. It was not until the 1970s that Flohé et al. discovered the presence of selenium at the active site of an enzyme, glutathione peroxidase 1 (GPx1) [4]. Later it was determined that selenium was at the active site in the form of a proteinogenic amino acid, selenocysteine (Sec) and that this Se was essential for the activity of the enzyme [5]. Since this first discovery, 25 selenoproteins have been identified that contain one or more Sec.

The RDA (recommended daily allowance) of Se for both men and women is $55 \mu \mathrm{g}(0.7 \mu \mathrm{mol}) /$ day [6]. In the diet the major forms of selenium are highly bioavailable. The Tolerable Upper Intake Level (UL) for adults is $400 \mu \mathrm{g}(5.1 \mu \mathrm{mol}) /$ day, based on selenosis as the adverse effect. Selenium deficiency 
compromises the selenium-dependent antioxidant system. Supplementation of selenium can maximize the expression and activities of selenium-dependent proteins and enzymes [7-9].

However, at levels above the UL, Se compounds are commonly thought to be associated with toxicity. Still, there have been many human clinical trials that show beneficial properties with very high, supranutritional levels of selenium, without significant toxicity [10,11]. At these high levels, selenoenzyme expression is not increased above levels associated with the RDA in humans [7-9]. Therefore, other mechanisms must contribute to the possible benefits of high-dose Se in the treatment of cancer. Metabolites of selenium compounds can contribute to hydrogen peroxide generation, perhaps via formation of superoxide, and cysteine oxidation and eventually DNA damage [12-14]. There appears to be potential for the use of these prooxidant traits of selenium in cancer therapies.

Cell culture models (i.e., in vitro) are used by researchers worldwide in the field of cancer research. The use of these models is a key first step before proceeding to preclinical animal studies. In 1985, Speier et al. suggested that cell culture media were deficient in Se [15]. They observed that this deficiency blunted the activity of GPx1 in HL-60 cells. Adding selenium to the cell culture medium overcame this deficiency as the activity of GPx1 was substantially increased. This work and the work of others indicated that Se is invariably deficient in cell culture media [16-18]. This observation is widely underappreciated.

This review focuses on the role of selenium in the prevention and treatment of cancer. We discuss the potential consequences of having insufficient selenium in in vitro models used in cancer research. We also summarize knowledge on the function of selenium when used in cancer treatment.

\section{Selenoproteins in Redox Biology and Cancer}

It is well accepted that selenoproteins are maximally expressed under sufficient nutritional selenium levels. Selenoproteins are a class of proteins, with or without enzymatic properties, that contain one or more selenium atoms usually in the form of a selenocysteine (Sec) moiety (Table 1). The family of Se-proteins is widely distributed throughout organs and tissues, where both ubiquitous and tissue-specific Se-proteins are expressed [19]. Selenoproteins have a wide variety of physiological roles, e.g., protection against oxidative stress, selenium transport, regulation of thyroid hormones, and synthesis of DNA. In addition, subcellular localization gives individual family members specificity for substrates and biological roles. Glutathione peroxidases (GPx), for example, have specific localized family members; GPx1 is predominantly abundant in the cytosol while GPx4 is mainly associated with the lipid bilayers of the cell membranes. While some functions may seem similar, e.g., removal of hydroperoxides, location is important for the substrate specificity of the enzyme. For GPx1 organic hydroperoxides must be solubilized to be a substrate, e.g., phospholipid hydroperoxides must be cleaved from a membrane by phospholipase $\mathrm{A}_{2}$ yielding a fatty acid, as a carboxylate, that is soluble in the cytosol [20]; whereas GPx4 acts on phospholipid hydroperoxides that are membrane-bound, i.e., localized within the phospholipid bilayer [21,22].

\subsection{Glutathione Peroxidases}

The glutathione peroxidase family was the first selenium-containing enzyme family identified $[4,5,23]$, making it one of the best characterized set of selenoproteins. GPx family members $1-4$, and 6 contain Sec at the active site of the enzyme. Other members rely on cysteine residues for activity. GPxs are generally thought to bring about the two-electron reduction of hydrogen peroxide or organic hydroperoxides (Equation (1)).

$$
\mathrm{ROOH}+2 \mathrm{GSH} \stackrel{\mathrm{GP}_{x}}{\rightarrow} \mathrm{ROOH}+\mathrm{H}_{2} \mathrm{O}+\mathrm{GSSG} \text {, where } \mathrm{R}=\mathrm{H} \text { is allowed }
$$

Selenium is found below sulfur in the periodic table of elements; thus, they share some chemical properties. The main difference is the bulky valence electron shell of selenium compared to sulfur. When integrated as selenocysteine into GPxs, this facilitates the reduction of hydrogen peroxide, 
and organic hydroperoxides, including lipid hydroperoxides. Upon reduction of these potential toxicants, the ionized selenol (R-Se $)$ at the active site of GPx is oxidized to selenenic acid ( $\mathrm{R}-\mathrm{SeOH}$ ). Two glutathione molecules provide the two electrons to reduce the active site selenenic acid back to selenol $[4,5,24]$.

The principal physiological role of GPx is to protect cells and tissues from oxidative fluxes of hydroperoxides. These fluxes occur through normal biological processes. For example, mitochondrial respiration generates superoxide that can be dismuted by superoxide dismutases (SOD) to hydrogen peroxide. Intra and extracellular superoxide is formed by NADPH oxidases, nitric oxide synthase, cytochrome p-450s, and xanthine oxidase [25]. Increased fluxes of superoxide can result in an increased steady-state level of hydrogen peroxide. If left unchecked, this can lead to the initiation of lipid peroxidation, oxidation of proteins, and oxidative DNA damage [26].

\subsubsection{GPx1}

GPx1, also known as cytosolic GPx as well as classic GPx, is one of the most abundant and ubiquitously expressed selenoproteins [27,28]. Its expression is influenced by oxidative eustress and oxidative distress as well as fluctuations in the availability of Se, making it one of the most sensitive selenoproteins [29]. Several studies have demonstrated an association between GPx1 and cancer when expression is repressed or reduced [24,26,30-32]. In MCF-7 breast carcinoma or mouse fibroblasts, GPx1 protects cells from DNA damage induced by UV light [33]. This effect was reversed when selenium was deficient in the cell culture media, consistent with a lower activity of GPx1. It has also been suggested that GPx1 can prevent the initiation of carcinogenesis through its counteractive role during the inflammation response of neutrophils [34]. Furthermore, estrogen can likely upregulate GPx1 upon oxidation of the NFKB cascade [35,36]. Hydroperoxides, a substrate for GPx1, can stabilize p53. This prevents tumor cells from proliferating and induces tumor-specific apoptosis [37]. Moreover, the promotor of Gpx1 contains a p53 binding site indicating that p53 can activate the transcription of GPx1. It appears that GPx1 mainly contributes to the prevention of oxidant-mediated toxicity that could result in the initiation of carcinogenesis. However, the antioxidant characteristic of GPx1 can prevent oxidant-induced apoptosis in transformed cells, resulting in progression of carcinogenesis and metastatic disease [38]. When overexpressed, GPx1 has been shown to protect cancer cells from highly oxidizing anti-cancer agents; the level of GPx1 also appears to correlate directly with advanced metastatic cancers [39-41].

\subsubsection{GPx2}

GPx2 is abundantly expressed in the gastrointestinal tract and is also detectible in the human liver. Its substrate selectivity is similar to that of GPx1. The role of GPx2 is considered to be the protection of the GI tract from oxidative damage. In a knockout study of the Gpx2 gene, increased apoptosis in colon crypt cells was observed during Se-deficiency [42], suggesting that Se-deficiency can affect the GI tract. Research by Emmink et al. indicates that silencing of Gpx2 results in sensitization to $\mathrm{H}_{2} \mathrm{O}_{2}$-induced apoptosis in patient-derived colonosphere cultures [43]. However, overexpression of GPx2 stimulated tumor growth, as well as differentiation, indicating a redox regulatory function of GPx2 in controlling tumorigenesis.

\subsubsection{GPx3}

This family member is secreted from the kidney into the blood. Approximately $20 \%$ of the Se found in plasma is present in GPx3 [44]. GPx3 appears to serve as an extracellular backup antioxidant for tissues that are exposed to high fluxes of oxidative distress, e.g., the heart [45]. It has been determined that extracellular GSH availability is significantly lower than intracellular [46]. Intracellular available GSH content can vary between 1 and $10 \mathrm{mM}$, while extracellular GSH content is estimated between 0.002 and $0.8 \mathrm{mM}$ [46-48]. The extracellular GSH concentration is highly variable due to tissue location e.g., $0.002 \mathrm{mM}$ in human plasma, up to $0.8 \mathrm{mM}$ in alveolar lining fluid $[47,48]$. While GPx3 has a lower 
rate constant, and thus less active than GPx1, it provides antioxidant activity as a peroxidase [49,50]. Therefore, it has been proposed that GPx3, as an antioxidant enzyme, ameliorates potential adverse consequences due to fluxes of ROS. Recycling of GPx3 will take longer due to the relative low availability of extracellular GSH. However, the crystal structure of GPx3 shows thioredoxin folds [50], suggesting a more complicated role for GPx3. Perhaps it has a role in regulating nitric oxide, where repression may lead to cardiovascular disorders [51]. Tumor suppressor functions of GPx3 have also been identified. Gpx3-deficient mouse models exhibit increased tumor incidence, as well as altered immune modulation of the tumor microenvironment [52].

\subsubsection{GPx4}

GPx4, also known as phospholipid hydroperoxide GPx, is associated with membranes, where it can reduce phospholipid hydroperoxides in situ. It has specific isoforms that are ubiquitously expressed for association with cellular membranes. It is localized "on" lipid membranes, in particular the nucleus and mitochondria [53]. GPx4 is a unique GPx family member because it is essential for life. Gp $x 4^{-/}$gene knockout murine models were shown to be embryonically (E7.5) lethal [54]. In contrast, heterozygote $G p x 4^{+/-}$mice are viable, but are much more sensitive to lipid peroxidation. However, in the mitochondrial sheet of spermatozoa GPx4 is transformed to function as a structural protein with no enzymatic activity [55].

Interest in GPx4 has increased due to renewed interest in its role in iron-mediated lipid peroxidation that leads to a nonapoptotic cell death, now referred to as ferroptosis [56]. GPx4 regulates lipid peroxidation by chemically reducing phospholipid hydroperoxides to their corresponding alcohol. During ferroptosis, the capacity of GPx4 to remove lipid hydroperoxides is inadequate to deal with the flux of lipid hydroperoxides, leading to cell death [57].

Phospholipid hydroperoxides are formed during propagation reactions of lipid peroxidation. The chain reactions of lipid peroxidation are initiated when a strong one-electron oxidant reacts with a bis-allylic hydrogen on a polyunsaturated lipid (Figure 1). This results in the generation of a carbon-centered radical on the phospholipid $\left(\mathrm{PL}^{\bullet}\right)$. This carbon-centered free radical can react with oxygen to form a phospholipid peroxyl radical (PLOO ${ }^{\bullet}$ ), which can then initiate new chains of free radical-mediated oxidations resulting in the formation of phospholipid hydroperoxides (PLOOH) [58]. Vitamin E can also facilitate the formation of PLOOH. This prevents the formation of a new carbon-centered phospholipid radical, preventing further propagation. If insufficient GPx4 activity is available, the steady-state level of PLOOH increases. Ferrous iron can react through a Fenton-like reaction with PLOOH, initiating new chain-branching reactions [59-61]. This in turn, can result in cell death, perhaps ferroptosis.

It is notable that the fundamental basics of this mechanism were observed in the 1950s by Schwarz and Folts [3]. In their studies, liver necrosis in rodents was prevented by Se, while deficient in vitamin E. Their observation supports the collaborative roles of vitamin E and GPx4 in the prevention of chain-branching reactions in lipid peroxidation brought about by redox active iron (Figure 1). However, it appears that GPx4 can compensate when vitamin E is limited. In contrast, if GPx4 activity is deficient, vitamin E alone will not prevent lipid peroxidation in a sustainable manner [62].

Thus, inhibition of GPx4 can lead to increased cell death, making this a potential target for cancer therapies. Currently, the link between GPx4 and ferroptosis is being comprehensively investigated by the scientific community. However, there is still not much unknown about the effects of GPx4 in earlier stages of cancer, e.g., carcinogenesis. In that setting, GPx4 may protect cells and tissues from lipid peroxidation, thereby preventing the initiation of cancer $[63,64]$.

GPx4 can alter the mammalian cell cycle, an important aspect in some cancer therapies [65]. There is also evidence from basic science studies that GPx4 protects cells from the lipid hydroperoxides formed from the generation of singlet oxygen by photosensitizers, a consideration in the mechanism of action of photodynamic therapy [66]. 


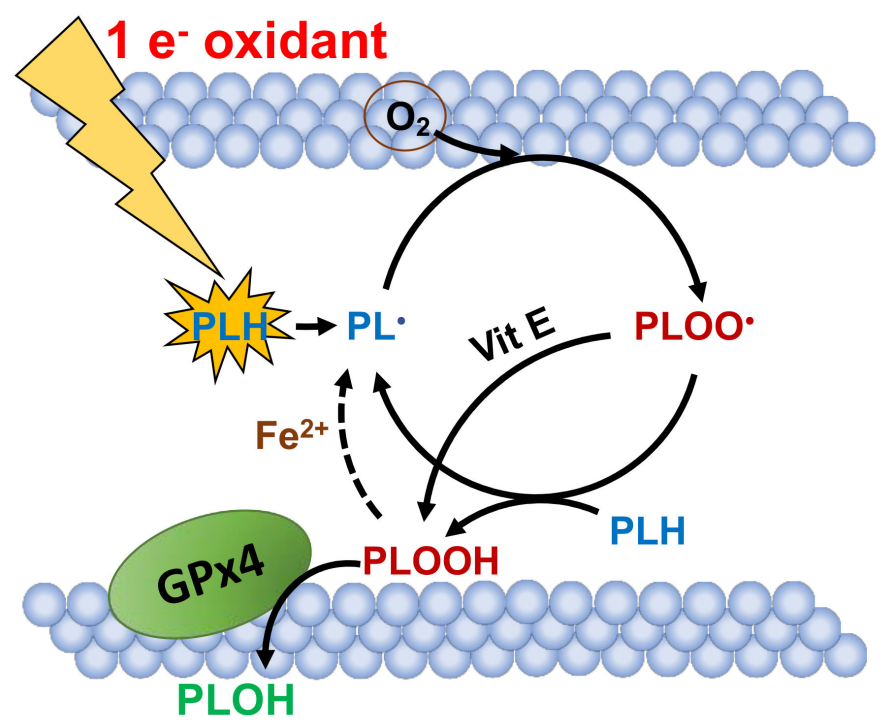

Figure 1. GPx4 activity is central to the termination of cellular lipid peroxidation. GPx4 plays an integral role in preventing iron-mediated lipid peroxidation nonapoptotic cell death, perhaps ferroptosis. GPx4, located in the lipid membrane, inhibits lipid peroxidation (LPO) by removal of PLOOH, a reactive phospholipid hydroperoxide, converting it to a non-reactive alcohol, $\mathrm{PLOH}$. Here, $\mathrm{PL}^{\bullet}$ is a carbon-centered radical on a phospholipid chain; $\mathrm{PLOO}^{\bullet}$ is a phospholipid peroxyl radical, and PLH represents a phospholipid with the $\mathrm{H}$ representing a bis-allylic hydrogen that readily reacts with peroxyl radicals to initiate a new chain of lipid peroxidation. Initiation of the first chain is done by a one-electron oxidant. Vitamin E and PLH are competing for reaction with PLOO ${ }^{\bullet}$; sufficient vitamin E will keep the reaction of $\mathrm{PLOO}^{\bullet}$ with $\mathrm{PLH}$ at a minimum, thereby inhibiting the formation of new chains of peroxidation reactions.

\subsection{Thioredoxin Reductases}

Thioredoxin reductases (TrxR) are homodimeric enzymes with a flavin FAD and NADPH binding site in each monomer [67]. The molecular weight of each monomer is $\approx 55 \mathrm{kDa}$. TrxR is present in higher eukaryotes including humans. The primary function of $\operatorname{Tr} x \mathrm{R}$ is reducing the oxidized form of thioredoxin (Trx) (TxrSS) [67-69]. The mechanism of this reduction involves FAD, NADPH, two cysteines residues and a selenocysteine near the catalytic site of TrxR. The substrate (TrxSS) oxidizes the Sec and a Cys residue of TrxR forming the reduced form of thioredoxin, $\operatorname{Tr} x(\mathrm{SH})_{2}$, and a Sec-Cys bond in TrxR. NADPH then provides two electrons to reset TrxR.

The major function of TrxR, as the name indicates, is the reduction of thioredoxin. This plays a central role in the thioredoxin node of the redox recycling system [69]. Thioredoxin is utilized for multiple processes. One function is as a secondary antioxidant because it recycles peroxiredoxins after they reduce hydrogen peroxide to water, forming TrxSS (Figure 2) [70]. For the synthesis and repair of DNA, Trx-(SH) $)_{2}$ acts as a reducing agent for ribonucleotide reductase, which converts ribonucleotides to 2-deoxyribonucleotides, also known as the D of DNA [71]. Finally, Trx-(SH) 2 acts as a redox-sensitive signaling molecule that can regulate cell growth, inhibit apoptosis, and it interacts with gene transcription factors like activator protein-1 [72].

Both protein and gene expression of TrxR are affected when selenium is deficient [73,74]. TrxR is up and downregulated when selenium levels are high or in deficiency, respectively. Although, the sensitivity of the individual family members is different, cytosolic $\operatorname{Trx}$ (TrxR1) appears to be less sensitive to Se-deficiency, which might be related to the essential nature of the enzyme [75].

In the mid-2000s, thioredoxin reductase was identified as a target for cancer therapy [76-78]. Cancer cells typically rely on aerobic glycolysis as a source for energy, known as the Warburg effect [79]. Additionally, a higher amount for glucose is required for the production of reducing equivalents in the pentose phosphate pathway (PPP). In the PPP, glucose is used as a source of electrons to reduce 
$\mathrm{NADP}^{+}$to NADPH. NADPH is used as a source of electrons that are shuttled down the Trx-cascade to counter oxidative distress (Figure 2). Tumor cells rely on this pathway to maintain redox balance, and thus viability and their capacity for cell division $[80,81]$. Therefore, inhibition of TrxR can sensitize tumor cells to oxidative damage and enhance tumor-specific cell killing [76,77,82,83]. This makes TrxR a promising target for cancer therapies.

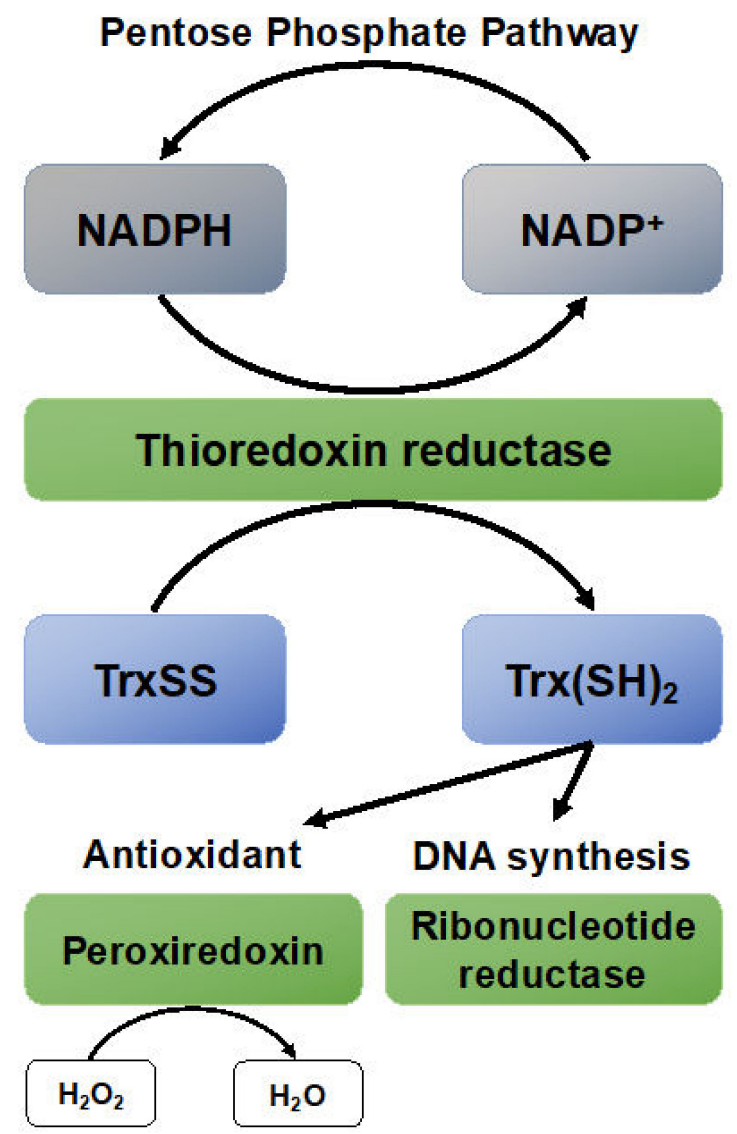

Figure 2. An overview of the function of thioredoxin reductases ( $\operatorname{Tr} x \mathrm{R})$ and thioredoxin $(\operatorname{Trx})$ in cell biology. Trx has multiple roles in its reduced form $\left(\operatorname{Tr} x(\mathrm{SH})_{2}\right)$. It can function as a signaling molecule, antioxidant, and is involved in DNA repair and synthesis. Shown are but two of the many functions of $\operatorname{Trx}(\mathrm{SH})_{2}$. For example, $\operatorname{Tr} x(\mathrm{SH})_{2}$ recycles methionine sulfoxide reductase B (MSRB) and is needed for the biology of nitric oxide and hydrogen sulfide.

\subsection{Iodothyronine Deiodinases}

The iodothyronine deiodinases (DIO) family, is a family of selenoenzymes with three individual members: types 1,2, and 3. The enzymes have a molecular weight of $29-33 \mathrm{kDa}$ and share similar sequence homology and catalytic properties [84]. In contrast to many other selenoproteins, DIOs are less involved in oxidative distress processes. DIOs are predominantly active in the thyroid hormonal system, where they convert T4 prohormone to T3. However, DIOs 1 and 3 can also inactive T4 by producing reverse T3, i.e., rT3. The activity of DIO1 is very sensitive to Se-deficiency, similar to GPx1, and can be readily increased by replenishing the Se content of cells and tissues [85]. Whereas, DIOs 2 and 3, like GPx4, reside high in the selenoprotein hierarchy. Selenoproteins high in this hierarchy are prioritized to receive Se when limited [86]. This can be further influenced by non-ubiquitous supply of Se to organs, and sex-specific selectivity. Other factors like iodine deficiency and high levels of thiocyanate in combination with Se-deficiency are related to Kashin-Beck disease or endemic myxedematous cretinism [87]. Several cancer types have been identified that express both high and low levels of DIOs. This can potentially lead to the loss of the control of cell proliferation in these 
cancers [88]. However, detailed mechanisms and understanding of the contribution of DIOs in cancer are still lacking.

\subsection{Methionine Sulfoxide Reductases B}

Methionine sulfoxide reductase B (MSRB), also known as selenoprotein R (SELENOR) is a Se-dependent family member of the methionine sulfoxide reductases [89]. While other MSR family members have a Cys residue at their active site, MSRB instead has a Sec moiety. The role of MSRB is to reduce oxidized methionine residues (methionine sulfoxide) in proteins back to methionine. Loss of function or knockout of the MSRB gene results in an increase in markers of oxidative distress in liver and kidney tissues, locations where this enzyme is most abundant [90]. In liver tissue this loss may increase the probability for hepatocellular carcinoma [91]. Other possible correlations between MSRB and cancer have yet to be identified.

\subsection{Selenoproteins}

Selenoproteins are not necessarily specified by a function-informing name. Most selenoproteins are as yet understudied and have been identified through genome sequencing [19]. These proteins have a wide variety of functions; some have a similar Cys-X-X-Sec motif like TrxR suggesting redox activity. Other selenoproteins contribute to protein structure via Sec-Cys bonds. A select subset of the better-studied members of this group, such as selenoprotein P (SELENOP), are discussed below. Table 1 provides an overview of most of these proteins with a brief description of their function.

\subsubsection{SELENOP}

Selenoprotein P is unique in the selenoprotein family. Most Se-containing proteins typically contain one Sec, SELENOP contains up to $10 \mathrm{Sec}$ residues. The large number of Se-containing residues in the protein suggests that it has a role in the transport of selenium. SELENOP knockout mouse models support the role of SELENOP in the transport of dietary Se to tissues [92,93]. SELENOP transports Se specifically into the brain and testes; SELENOP knockout mouse models suffer from neurological problems and male sterility. When dietary intake of Se is limited, liver tissue can readily take up Se to incorporate it into SELENOP, where it is secreted into the plasma for transport to other tissues [94]. Reuptake of SELENOP in tissues is regulated by at least two different receptors: apolipoprotein E receptor-2 for the brain and testis [95,96], and megalin, a lipoprotein receptor in the proximal tubule from the kidney [97]. Since SELENOP is mainly linked to the transport of Se, its expression may be used to determine the prognosis of cancer patients [98]. However, lower SELENOP levels may be caused by insufficient intake of Se and can be simply reversed by supplementation. In addition, SELENOP biosynthesis is decreased during the inflammatory response, i.e., acute-phase response, disrupting Se transport and metabolism of Se [99]. This can potentially contribute to the reduced Se status of cancer patients. Furthermore, a reduction of SELENOP and Se in plasma was observed 1 day after minor elective surgery in mice [100]. These examples clearly show that SELENOP and Se distribution can be blunted by inflammation, with the potential to sensitize humans to oxidative stressors. In addition, single nucleotide polymorphisms in the human SELENOP gene show an altered response to dietary intake of Se [101]. This could also limit Se transport, resulting in decreased activities of Se-dependent enzymes and increasing the susceptibility of the initiation of cancer [102]. 
Table 1. An overview of 24 selenoproteins and some of their functions.

\begin{tabular}{|c|c|c|}
\hline Selenoprotein & Function & Reference \\
\hline GPx1 & $\begin{array}{l}\text { Reduction of solubilized organic hydroperoxides and hydrogen peroxide in } \\
\text { the water space of cells, cytosol, mitochondria, nucleus }\end{array}$ & {$[23,103]$} \\
\hline GPx2 & $\begin{array}{l}\text { Abundantly expressed in tissues of the liver and GI tract. Similar function } \\
\text { to GPx1 }\end{array}$ & [42] \\
\hline GPx3 & Extracellular GPx, regulation of nitric oxide & {$[45,51]$} \\
\hline GPx4 & $\begin{array}{l}\text { Reduction of lipid hydroperoxides, essential for the termination of lipid } \\
\text { peroxidation; prevents ferroptosis }\end{array}$ & {$[53,73]$} \\
\hline GPx6 & Only found in humans, no specific role has yet been identified & [19] \\
\hline TrxR1 & $\begin{array}{c}\text { Reduces } \operatorname{TrxSS} \text { to } \operatorname{Trx}(\mathrm{SH})_{2} \text {, vitamin } \mathrm{C} \text {, polyphenols, and other substrates to } \\
\text { regulate intracellular redox environment }\end{array}$ & [67] \\
\hline $\operatorname{Tr} x \mathrm{R} 2$ & Located in mitochondria, control and regulates redox environment & [19] \\
\hline TrxR3 & Abundant in testes, reduces mitochondrial glutathione disulfide & [19] \\
\hline DIO1 & $\begin{array}{c}\text { Converts T4 (thyroxine) into T3 (active thyroid hormone) and inactivates T4 } \\
\text { to rT3 }\end{array}$ & [84] \\
\hline $\mathrm{DIO} 2$ & Converts $\mathrm{T} 4$ into $\mathrm{T} 3$ & [84] \\
\hline DIO3 & Inactivates $\mathrm{T} 4$ to $\mathrm{rT} 3$, as well as $\mathrm{T} 3$ to $\mathrm{T} 2$ & [84] \\
\hline MSRB & $\begin{array}{l}\text { Restores oxidatively damaged methionine (Met-sulfoxide) to native } \\
\text { configurations }\end{array}$ & [89] \\
\hline SELENOF & Oxidoreductase that may assist in disulfide formation and protein folding & [104] \\
\hline SELENOH & Regulates GSH synthesis during embryonic development & [19] \\
\hline SELENOI & Functions as a phospholipid synthase & [19] \\
\hline SELENOK & Abundant in myocytes, function is currently unclear & [19] \\
\hline SELENOM & Abundant in myocytes, function is currently unclear & [105] \\
\hline SELENON & $\begin{array}{c}\text { Interacts with ryanodine receptor, mutations result in congenital } \\
\text { muscular dystrophy }\end{array}$ & [73] \\
\hline SELENOO & Suggestive redox function due to Cys-X-X-Sec motif & [19] \\
\hline SELENOP & $\begin{array}{l}\text { Plasma selenium transport protein, contains up to } 10 \mathrm{Sec} \text {, exhibits very low } \\
\text { GPx4-like activity when purified }\end{array}$ & {$[92,93]$} \\
\hline SELENOS & Suggested to be involved in ER stress response & [19] \\
\hline SELENOT & Suggested role in $\mathrm{Ca}^{2+}$ mobilization & [19] \\
\hline SELENOV & Suggestive redox function due to Cys-X-X-Sec motif & [19] \\
\hline SELENOW & $\begin{array}{l}\text { Expressed in a variety of tissues and may regulate redox state of } \\
\qquad 14-3-3 \text { proteins }\end{array}$ & [19] \\
\hline
\end{tabular}

\subsubsection{SELENOF and SELENOM}

Selenoprotein $\mathrm{M}$ and selenoprotein $\mathrm{F}$ are $15 \mathrm{kDa}$ proteins that have $31 \%$ similarity in sequence; both are localized in the endoplasmic reticulum (ER) [106]. They contain a typical thioredoxin-like fold and have Cys-X-X-Sec motifs, which suggests redox activity as thiol-disulfide oxidoreductases [105]. Both enzymes are associated with protein-folding in the ER. However, the evidence of this functionality in vivo is scarce [104]. A recent report of SELENOM suggests that it can play a role in the progression of renal cell carcinoma [107]. Furthermore, SELENOF was suggested to play a similar role in colon cancer [108].

\subsection{Selenium Deficiency in Cell Culture}

Many drug development and cancer therapy studies rely on in vitro models to screen for cellular adverse effects. It was suggested in 1985 by Speier et al. that cell culture medium is deficient in selenium [15]. By simply adding selenium to the cell culture medium, maximum GPx activity was achieved. Later, other labs showed increases of selenium-dependent enzyme activities upon supplementation with selenium. Table 2 is a list showing increased enzyme activities in various cell lines once supplemented with Se. These studies indicate that selenium-deficiency prevents maximum Se-dependent activities across cell culture models, thereby impacting single or multiple functions. 
Table 2. Supplementing cell culture media with Se increases Se-dependent enzyme activities.

\begin{tabular}{|c|c|c|c|c|}
\hline $\begin{array}{l}\text { Concentration } \\
\text { Supplemented }\end{array}$ & $\begin{array}{l}\text { Enzyme } \\
\text { Studied }\end{array}$ & Fold Increase $^{b}$ & Cell Line & Reference \\
\hline $4 \mathrm{nM}$ & GPx1 & 3 & Human bronchial epithelial & [109] \\
\hline $50 \mathrm{nM}$ & $\begin{array}{l}\text { GPx1, } \\
\text { GPx4 }\end{array}$ & $\begin{array}{l}3-15^{c}, \\
3-10^{c}\end{array}$ & L929, HepG2, D10N, THP-1, ECV 304 & [17] \\
\hline $100 \mathrm{nM}$ & $\begin{array}{l}\text { GPx1, } \\
\text { TrxR }\end{array}$ & $\begin{array}{r}2, \\
1.5\end{array}$ & Bone marrow stromal & [110] \\
\hline $100 \mathrm{nM}$ & $\begin{array}{l}\text { GPx1, } \\
\text { GPx4, } \\
\text { TrxR }\end{array}$ & $\begin{array}{r}2, \\
2 \\
1.5\end{array}$ & Jurkat, T-leukemia & [111] \\
\hline $200 \mathrm{nM}^{\mathrm{d}}$ & $\begin{array}{l}\text { GPx1, } \\
\text { GPx4, } \\
\text { TrxR }\end{array}$ & $\begin{array}{l}3, \\
3, \\
2\end{array}$ & HepG2, MIA PaCa-2 & [18] \\
\hline $2 \mu \mathrm{M}$ & GPx1 & 17 & RAW 264.7 macrophage & [112] \\
\hline
\end{tabular}

${ }^{a}$ as sodium selenite, ${ }^{b}$ fold increases vs. selenium deficient, ${ }^{c}$ fold increase range over cell lines, ${ }^{d}$ as selenomethionine.

\section{The Role of Selenium in Cancer Prevention}

Selenium as a trace nutrient has been proposed to prevent certain types of cancer [113]. In these studies, cohorts were compared that have low vs. high dietary intake of selenium. A systematic review by Vinceti et al. found several studies with inverse associations between selenium intake and the risk of certain types of cancer [10]. However, most studies show no significant cancer preventative properties for Se. The results of a study conducted by the National Cancer Institute, Selenium and Vitamin E Cancer Prevention Trial (SELECT), reported an increased risk of prostate cancer development among men supplemented with vitamin $\mathrm{E}[113,114]$. It is important to note that subjects enrolled for this trial had relatively high Se status, $135 \mathrm{ng} / \mathrm{mL}$ in serum [115] (normal recommended range $\approx$ 110-130 ng/mL [116]). In fact, populations in Europe typically have lower Se intake than populations in North America [117]. Therefore, the SELECT study would have been better off with a cohort that was Se-deficient. Such a study may reveal any potential cancer preventative effects of $S e$ in a population that has average intake of Se $[115,116]$.

Various mechanisms have been proposed for how Se might prevent cancer. Several Se compounds have been shown to prevent the initiation of cancer through point mutations that were a result of covalent DNA adducts [118]. Selenium inhibited carcinogenesis by known initiators in mammary, lung, liver, and colon tissues in rats $[118,119]$. In a later study, selenium-enriched garlic was shown to induce enzymes responsible for phase I and phase II metabolism. This suggested that with Se, carcinogens are more readily detoxified and excreted [120]. On the other hand, induction of phase I metabolic enzymes can bioactivate some carcinogens. For example, members of the cytochrome P450 superfamily can bioactivate polyaromatic hydrocarbons, such as benzo(a)pyrene, to benzo(a)pyrene-7,8-dihydrodiol-9,10-epoxide. This highly reactive metabolic intermediate induces mutations on the tumor suppressor gene p53 [121-123]. Hence, it is unlikely that induction of phase I enzymes by selenium-enriched garlic was responsible for the inhibition of carcinogenesis.

Unsurprisingly, most trials have found no significant impact of Se on the incidence of cancer. Clark et al. published a report on a double-blind randomized controlled trial with a cohort of 1312 patients treated with $200 \mu \mathrm{g} \times \mathrm{d}^{-1}$ of selenium [124]; the RDA is $55 \mu \mathrm{g} \times \mathrm{d}^{-1}$. After a mean treatment period of $4.5 \mathrm{y}$, no statistical differences were found in the incidence of basal or squamous cell carcinoma of the skin. Results from the secondary endpoints of this study did suggest decreases in the incidence and mortality of other carcinomas. From a phase III clinical trial where Se was tested as an agent to prevent prostate cancer in men with high-grade prostatic intraepithelial neoplasia (SWOG S9917), Marshall et al. (2011) reported a small nonsignificant decrease in prostate cancer risk between patients that were treated with $200 \mu \mathrm{g}$ daily vs. one of the placebo groups [125]. This subset contained subjects with the lowest quartile of Se concentrations in blood. For all other subsets in this study, Se did not affect prostate cancer risk. In 2013 a Phase III clinical trial (ECOG 5597) reported that $200 \mu \mathrm{g} \times \mathrm{d}^{-1}$ did not affect the prevention of the formation of second primary tumors in stage 1 non-small-cell 
lung cancer patients [126]. In that same year, a Phase III clinical trial conducted at the University of Arizona Cancer Center investigated the effect of Se in men with high risk for prostate cancer; 200 or $400 \mu \mathrm{g} \times \mathrm{d}^{-1}$ did not affect the incidence of prostate cancer compared to the placebo-controlled cohort with high risk.

It is well accepted that optimal selenium intake $\left(\approx 55-75 \mu \mathrm{g} \times \mathrm{d}^{-1}\right)$ saturates the expression of selenoproteins in the plasma [7-9]. Thus, supranutritional amounts of Se may not provide additional benefit to humans from the selenium-dependent antioxidant system (Figure 3). Other mechanisms have since been proposed to explain the cancer prevention potential of Se. In 1990, Ip and Ganther suggested that redox-active metabolites of selenium may be important in the prevention of cancer [127]. It was later understood that these redox-active metabolites of selenium may not halt the initiation of carcinogenesis, but instead can be used for the treatment of cancer.

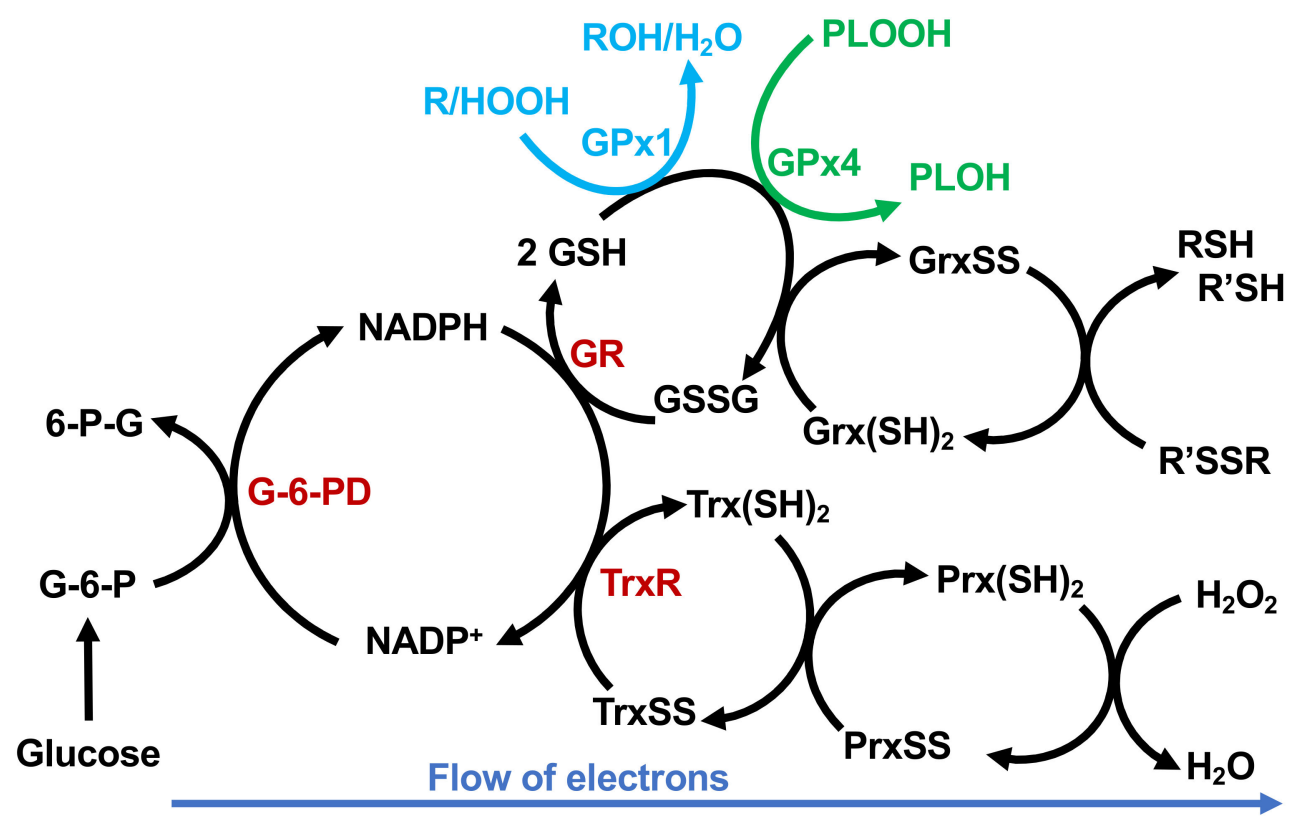

Figure 3. The selenium-dependent antioxidant system of glutathione peroxidases (GPx) and thioredoxin reductases (TrxR). Reducing equivalents necessary to counter unwanted oxidations are obtained from glucose via the pentose phosphate pathway. Glucose-6-phosphate dehydrogenase (G6PD) reduces $\mathrm{NADP}^{+}$to NADPH, which in turn is used by glutathione disulfide reductase (GR) and thioredoxin reductase (TrxR) to reduce glutathione disulfide (GSSG) and oxidized thioredoxin (TrxSS) back to 2GSH and $\operatorname{Tr} x(\mathrm{SH})_{2}$, respectively. Glutathione "recycles" GPx enzymes, e.g., GPx1 and GPx4. NAPDH is also a cofactor for the reduction of TrxSS, carried out by TrxR. GSH and the GPxs along with $\operatorname{Trx}(\mathrm{SH})_{2}$ and peroxiredoxins $\left(\operatorname{Prx}(\mathrm{SH})_{2}\right)$ work via separate nodes to reduce $\mathrm{H}_{2} \mathrm{O}_{2}$ to $\mathrm{H}_{2} \mathrm{O}$. Adapted from [69].

Se has also been suggested to protect from DNA damage through redox factor-1 (REF1)-modulated stabilization of p53 [128-130]. This oncogene is typically inactive in tumor cells, thus, this effect is thought to protect normal cells during cancer therapies. However, these experiments used cell culture models, and may not have considered that cell culture medium is Se-deficient [18]. Thus, these observations may have been "normal" cell physiology and protection from DNA damage only occurs through this pathway when Se-sufficient.

\section{Redox Active Selenium}

\subsection{Selenium at an Active Site of an Enzyme Is Typically More Reactive Than Its Sulfur Counterpart}

In the periodic table of elements, selenium is located in group 16, i.e., the chalcogens. Thus, it has similar chemical properties in biology when compared to sulfur. A key difference between sulfur and 
selenium, when incorporated into the active site of enzymes as either Cys or $\operatorname{Sec}$ is the $\mathrm{pK}$ a (Equations (2) and (3)) [131,132]. Sulfur, as thiol, is incorporated into proteins via cysteine (Cys-SH). Selenium, as selenol, is incorporated into proteins and enzymes as selenocysteine (Cys-SeH). At physiological $\mathrm{pH}=7.4$, the thiol of cysteine remains mainly protonated, $\approx 90 \%$ as $(\mathrm{Cys}-\mathrm{SH})$. However, the lower $\mathrm{p} K_{\mathrm{a}}$ of selenocysteine results in $>99 \%$ being deprotonated, existing as $\mathrm{Cys}_{-} \mathrm{Se}^{-}$. In general, this difference results in a much greater nucleophilicity of selenocysteine, compared to $\mathrm{Cys}-\mathrm{SH}$ at $\mathrm{pH}=7.4$. Thus, Cys-Se is much more reactive, for example with hydroperoxides. However, it must be kept in mind, that the effective $\mathrm{p} K_{\mathrm{a}}$ of Cys-SH in a protein can vary widely, depending on the local environment.

$$
\begin{aligned}
& \text { Cys-SH } \rightarrow \text { Cys-S }^{-}+\mathrm{H}^{+} \quad \mathrm{pK}_{\mathrm{a}}=8.5 \\
& \text { Cys-SeH } \rightarrow \text { Cys-Se }^{-}+\mathrm{H}^{+} \quad \mathrm{pK} K_{\mathrm{a}}=5.2
\end{aligned}
$$

Selenium is central to the activity of many redox enzymes (Figure 3). By protecting cells and tissues from oxidative distress, it regulates and maintains the redox status of cells and tissues [133-135]. However, inorganic sources for selenium in supranutritional concentrations have been found to exhibit pro-oxidant characteristics [14]. The oxidation state of Se in inorganic sodium selenite and methylseleninic acid is +4 ; thus, they can directly oxidize cysteine residues in catalytic subunits of enzymes [136]. Many studies on selenium have utilized supranutritional doses of selenium, which show anti-cancer effects. However, when inorganic forms are used, the window for potential toxicity is greatly increased [137]. Thus, it is important to select the appropriate form of Se, which will depend on the goal for its use. The toxic characteristics of inorganic selenium may be preferred.

\subsection{The Pro-oxidant Side of Selenium}

Selenium is generally known for its potential toxicity. In 2009, an overdose of selenium administered intravenously, as selenite, led to the death of 21 polo ponies [138]. This acute toxicosis was proposed to be caused by the oxidation of cysteine residues of proteins and enzymes resulting in their impaired function $[13,139]$. Human subjects were also exposed to high doses of Se, due to a misformulation of a dietary supplement $[140,141]$. The estimated mean intake of Se varied between 20,000 and $40,000 \mu \mathrm{g} \times \mathrm{d}^{-1}$ (recommend dietary allowance is $55 \mu \mathrm{g} \times \mathrm{d}^{-1}$ ). Thankfully, there were no acute deadly cases, however a large number of short- and long-term adverse effects were observed. Some of the reported symptoms included diarrhea, brittle nails or discoloration, loss of nails or hair, joint pain, and fatigue. In these formulations the source for Se was sodium selenite, an inorganic form of Se. It is comparable to other forms of selenium, e.g., sodium selenate and methylseleninic acid $\left(\mathrm{H}_{3} \mathrm{CSe}(=\mathrm{O}) \mathrm{OH}\right)$, which can be quite toxic due to their ability to oxidize thiols (Equations (4)-(6)), with associated formation of reactive oxygen species such as superoxide and hydrogen peroxide (Equations (7)-(9)) [142-146], while other forms show very little toxicity, for example selenomethionine $[18,143,144]$. Example reactions with thiols, using glutathione (GSH) as an example thiol, are:

$$
\begin{gathered}
\mathrm{SO}_{3}{ }^{2-} \text { (selenite) }+4 \mathrm{GSH} \rightarrow \mathrm{GSSG}+\mathrm{GSSeSG}+\mathrm{H}_{2} \mathrm{O}+2 \mathrm{OH}^{-} \\
\mathrm{GSSeSG}+\mathrm{GSH} \rightarrow \mathrm{GSSG}+\mathrm{GSSeH} \\
\mathrm{GSSeH}+\mathrm{xGSH}+\mathrm{O}_{2} \rightarrow \mathrm{GSSG}+\mathrm{R}-\mathrm{SeH}+\mathrm{H}_{2} \mathrm{O}_{2}
\end{gathered}
$$

In Equation (6) GSSeH reacts with additional thiols to form more disulfides as well as $\mathrm{H}_{2} \mathrm{O}_{2}$, potentially through a superoxide intermediate. $\mathrm{R}-\mathrm{SeH}$ represents an array of Se-containing species. The reactions of methylseleninic acid are parallel:

$$
\begin{gathered}
\mathrm{H}_{3} \mathrm{CSe}(=\mathrm{O}) \mathrm{OH}+2 \mathrm{GSH} \rightarrow \mathrm{GSSG}+\mathrm{H}_{3} \mathrm{CSeOH} \\
\mathrm{H}_{3} \mathrm{CSeOH}+2 \mathrm{GSH} \rightarrow \mathrm{GSSG}+\mathrm{H}_{3} \mathrm{CSeH}
\end{gathered}
$$




$$
\mathrm{H}_{3} \mathrm{CSeH}+2 \mathrm{GSH}+\mathrm{O}_{2} \rightarrow \mathrm{GSSG}+\mathrm{H}_{2} \mathrm{O}_{2}
$$

In Equation (9), $\mathrm{H}_{3} \mathrm{CSeH}$ (methyl selenol) reacts with additional thiols, probably via $\mathrm{H}_{3} \mathrm{CSe}^{-}$ $\left(\mathrm{p} K_{\mathrm{a}}\left(\mathrm{H}_{3} \mathrm{CSeH}\right)=5.2\right)$, catalytically generating $\mathrm{H}_{2} \mathrm{O}_{2}$ and additional disulfides [143]. Although the reactions above are shown with GSH, these reactions would also occur with other cellular thiols including protein thiols. Thus, not only will GSH be depleted, but also NADPH. The oxidation of thiols in proteins to disulfides, including mixed disulfides, will have many downstream consequences, including enzyme inactivation.

As an example, Se can decrease the DNA binding affinity of NFKB and AP-1 by facilitating the oxidation of cysteine residues, resulting in a reduction of cytokine production [147-149]. Other redox-sensitive enzymes, as well as redox signaling proteins are shown to be affected by high levels of selenium. Thiol oxidation, induced by selenium, inhibited activities of several kinases, caspase-3, prostaglandin synthesis, and mitochondrial function [148,150-156]. These examples clearly show the wide range of targets that could be altered by selenium-induced oxidation.

\subsection{Cancer Therapies Utilizing Selenium}

The potential to increase cellular oxidative distress with appropriate Se-compounds could be an important consideration in cancer therapy. Redox-active Se-compounds have pro-oxidant properties, increasing the formation of ROS. Cancer cells are thought to have higher steady-state levels of ROS compared to their normal cell counterparts [133,157-160]. Therefore, combining these properties may tip the oxidative balance of cancer cells to an even greater degree of distress by generating additional reactive oxygen species, e.g., superoxide $\left(\mathrm{O}_{2}{ }^{\bullet-}\right)$ and hydrogen peroxide $\left(\mathrm{H}_{2} \mathrm{O}_{2}\right)$. In general, normal cells can manage an increase in the flux of oxidants. However, it is proposed that cancer cells are at their limit of ability to control oxidative distress. Generating more ROS through an appropriate pro-oxidant Se-compound would take advantage of these differences, providing a therapeutic advantage.

Many publications show the pro-oxidant side of selenium compounds. Sodium selenite and selenocystamine have been shown to increase oxidative DNA lesions, e.g., 8-hydroxydeoxyguanosine [142]. Additionally, apoptosis appears to be readily induced by sodium selenite, as well as single-strand DNA breaks [161-165]. However, selenomethionine does not exhibit similar adverse effects.

Inhibition of neoplastic growth was shown by redox-active selenium, selenite $(5 \mu \mathrm{M})$, selenium-di-glutathione $(5 \mu \mathrm{M})$ in HeLa Cells. However, a non-redox active selenium compound, Se-DL-cystine showed inhibition at much higher concentrations $(100 \mu \mathrm{M})$ [166]. Furthermore, changes in the half-cell reduction potential (more positive) were observed as more GSH was oxidized. These observations suggest that these compounds cause cell death to HeLa cells via three different pathways. Overall, selenite led to a more positive redox environment in cells resulting in necroptosis.

Selenium-di-glutathione was suggested to cause glutathionylation/oxidation of death receptors resulting in apoptosis. Whereas, Se-DL-cystine causes ER stress, resulting in apoptosis or cell death [166].

Due to the ROS formed and the ability to oxidize intracellular thiols, redox-active selenium compounds can activate Nrf2 [167]. Upon oxidation of Keap1, Nrf2 is released in the cytosolic fraction of cells [168]. Nrf2 then acts as a transcription factor binding to the antioxidant response element (ARE) [169]. Activation of the ARE upregulates the transcription of a large array of antioxidant, phase I, and phase II detoxifying enzymes [170,171]. Two of these target enzymes are selenoenzymes: GPx2 and TrxR1 [172]. It is now understood that activation of Nrf2 can protect normal cells against the initiation of cancer. However, transformed cells will most likely benefit equally from this phenomenon, resulting in further progression of the disease [167].

In addition to small molecular forms of Se, nanoparticles of Se have been proposed for use in cancer treatment. The main benefit of nanoparticles in cancer treatment is added functionality. A monolayer of molecules functionalizes the particles to gain specific properties. Liu et al. functionalized Se nanoparticles $(300-500 \mathrm{~nm})$ with folate [173]. This guides the nanoparticles to cancer cells, which often 
overexpress the folate receptor. The core of the nanoparticles was made of selenite, which is released locally, upon binding to the folate receptor. This specific model showed relatively high cytotoxicity in HepG2 and multi-drug resistance HepG2 cell lines. In contrast, there was no change in hematological values, nor was liver toxicity observed in female rats exposed to a relatively high dose of $5 \mathrm{mg} \mathrm{kg}^{-1} \mathrm{Se}$ nanoparticles (20 nm) [174].

Selenium can also be used in supplemental quantities, $<0.5 \mathrm{mg} \mathrm{d}^{-1}$, as an adjuvant for chemo and radiation therapy $[175,176]$. Muecke and colleagues suggested that cancer patients that have been treated with chemo or radiation therapy could benefit from supplementation of Se. It could restore selenium-deficiency and alleviate side-effects of cancer therapies. Se-deficient patients were enrolled for a phase 3 clinical trial, and Se successfully reduced radiation therapy induced diarrhea, while not affecting the effectiveness of the anticancer therapy.

In 2014, the 10-year survival rate seen in this phase 3 trial was increased in the Se supplemented group, albeit not significant, $p=0.09$ [175]. It is interesting whether this effect was caused by restoring the selenium-dependent antioxidants due to possible Se-deficiency or other less familiar mechanisms. At these low, supplemental concentrations, Se may only have a restoring effect for selenoproteins and enzymes, since most selenium compounds do not start to show any toxicity at these lower concentrations.

Selenium compounds can have a large variety of properties (Table 3). It is important to understand which compound to select for use in an experimental design. Selenium compounds have been developed to have slightly different properties; however, one major property is shared; any selenium compound appears to increase selenoenzyme expression and activities when the amount of accessible Se is limited [133]. For example, supplementing Se-deficient cell culture media with 500 nM SLM or sodium selenite, will both achieve maximum GPx1 activity. Yet, sodium selenite can increase the flux of superoxide at 1-10 $\mu \mathrm{M}$ concentrations, whereas SLM will not. Therefore, it is important to understand the different properties of Se compounds during the design of any biomedical experiments. In cancer therapy, inorganic forms, such as sodium selenite, are most likely preferred due to their pro-oxidant nature.

\subsection{High Dose Organic Selenium}

Most cancer therapies that utilize selenium rely on the pro-oxidant properties of inorganic Se. However, at The University of Iowa seleno-L-methionine (SLM), an organic source for Se, is being used in a clinical trial (NCT02535533) [177,178]. This phase I/II trial employs high dose SLM as an adjuvant in the treatment of renal cell carcinoma (RCC). SLM can be administered in much higher doses compared to inorganic forms [137]. In contrast, the therapeutic window of inorganic forms of Se is much smaller due to dose-limiting toxicities [179]. At these high doses of SLM, new therapeutic phenomena occur. SLM, as well as methyl-selenocysteine, show enhanced drug delivery to the tumor [180-182]. In addition, these compounds have been shown to effectively inhibit Hypoxia-Induced Factors-1 $\alpha$ and $-2 \alpha$ (HIFs), which are highly expressed in RCC [183-187]. SLM is currently being tested in metastatic RCC patients in combination with Axitinib, a vascular endothelial growth factor receptor (VEGFR) inhibitor in recurrence and refractory setting. SLM at different dose levels $(2500,3000$, and $4000 \mu \mathrm{g})$ was administered orally twice daily for a 14-d run-in period, followed by once daily dosing in combination with Axitinib $5 \mathrm{mg}$ twice daily until disease progression or unacceptable toxicity. Eligible patients must have clear cell RCC histology and have progressed on at least one prior treatment. The primary objective of the study is to evaluate the safety of the combination, and the recommended Phase 2 dose (RP2D) of SLM, secondary endpoint is to evaluate the preliminary efficacy as measured by objective response rate (ORR), progression free survival (PFS) and overall survival (OS). Preliminary results of 12 evaluable patients were presented at ESMO 2019 [188], showing that high dose SLM, $4000 \mu \mathrm{g}$ twice daily for 14 days followed by once daily, in combination with Axitinib, was safe with promising efficacy; two patients achieved complete response (CR) for at least 2 years; four patients achieved partial response. No dose-limiting toxicities were noted. A Phase 2 trial is currently ongoing with SLM 
$4000 \mu \mathrm{g}$ and Axitinib $5 \mathrm{mg}$ twice daily. This research has opened new opportunities to use Se as a drug, rather than a supplement.

SLM can be incorporated into proteins and enzymes instead of a methionine $[189,190]$. This may lead to difficulties to interpret the information gained from a clinical trial. Besides changes in Se-dependent proteins and enzymes, many other factors change, which makes it hard to pin-point what caused the effect [116].

Table 3. Selenium compounds and corresponding properties.

\begin{tabular}{|c|c|c|c|}
\hline Compound & $\mathrm{IC}_{50} \mathrm{a}(\mu \mathrm{M})$ & Comments & Reference \\
\hline Sodium selenite & $1-10$ & $\begin{array}{c}\text { Inorganic source for Se } \\
\text { Most widely used Se source } \\
\text { Pro-oxidant in high concentrations } \\
\text { Administered IV to reach pharmacological doses }\end{array}$ & {$[142,166]$} \\
\hline Sodium selenate & $1-10$ & $\begin{array}{l}\text { Inorganic source for Se } \\
\text { Suggested to play a role in obesity } \\
\text { Organic source for Se }\end{array}$ & [191] \\
\hline Seleno-L-methionine & $>100$ & $\begin{array}{c}\text { Abundant dietary source for Se } \\
\text { Can be incorporated in proteins as Se-methionine } \\
\text { Relative low toxicity }\end{array}$ & {$[137,142,192]$} \\
\hline Methyl selenocysteine & $>100$ & $\begin{array}{c}\text { Organic source for Se } \\
\text { Inhibitor of angiogenesis } \\
\text { Synthetic organic Se compound }\end{array}$ & [133] \\
\hline Methyl seleninic acid & $1-10$ & $\begin{array}{c}\text { Potential to alter the immune response in tumors } \\
\text { Pro-oxidant properties } \\
\text { Enhances tumor cell killing }\end{array}$ & {$[193,194]$} \\
\hline Selenium-di-glutathione & 5 & $\begin{array}{l}\text { Organic source for Se } \\
\text { Product of selenite reduction by GSH } \\
\text { Organic source for Se }\end{array}$ & {$[166,195]$} \\
\hline Se-DL-cystine & $5-100$ & $\begin{array}{l}\text { Both antioxidant and pro-oxidant } \\
\text { Exhibit GPx-like activity under reducing } \\
\text { conditions }\end{array}$ & {$[133,166]$} \\
\hline Selenocystamine & $25-50$ & $\begin{array}{c}\text { Organic source for Se } \\
\text { Non-catalytic } \\
\text { Prevents DNA oxidation }\end{array}$ & [142] \\
\hline Se-adenosyl-L-selenomethionine & N.D. & $\begin{array}{l}\text { Synthetic organic Se compound } \\
\text { Proposed substrate for methyltransferases }\end{array}$ & [196] \\
\hline Ebselen & $5-50$ & $\begin{array}{c}\text { Synthetic organic Se compound } \\
\text { GPx mimic } \\
\text { Antioxidant scavenger } \\
\text { Anti-inflammatory }\end{array}$ & [197-199] \\
\hline Selenophene & $0.1-10^{\mathrm{b}}$ & $\begin{array}{c}\text { Synthetic organic Se compound } \\
\text { Antioxidant properties } \\
\text { Protect against } \mathrm{CCl}_{3} \text { induced liver damage } \\
\text { Molecular building block for anti-cancer agents } \\
\text { Synthetic inorganic Se particles }\end{array}$ & {$[200,201]$} \\
\hline Selenium nanoparticles & $<1$ & $\begin{array}{l}\text { Much lower apparent toxicity in vivo } \\
\text { Induces oxidative stress in vitro }\end{array}$ & {$[173,174]$} \\
\hline
\end{tabular}

\footnotetext{
${ }^{\mathrm{a}} \mathrm{IC}_{50}$ as inhibition of growth, determined in vitro. ${ }^{\mathrm{b}}$ Selenophene is considered a "building block" molecule. Adding functional groups to the main ring structure can change the toxicity of selenophene, making it highly variable and customizable.
}

\section{Discussion}

Selenium-dependent enzymes have many roles in the maintenance of optimal human health. The majority of selenoproteins and enzymes have roles in the prevention of carcinogenesis. However, selenium deficiency decreases the expression and activities of selenoproteins and enzymes, affecting their cancer preventative properties. Thus, it is important to prevent selenium deficiency.

Cell culture studies are essential basic studies for many labs around the world. However, selenium deficiency in the media is often not considered by laboratories that use cell culture models. Cell culture medium, containing $10 \%$ fetal bovine serum as a sole source for Se, is typically quite deficient in Se. This reduces the antioxidant capacity of cells; these cells are less able to handle an oxidative challenge. We have proposed that supplementation with Se should always be an integral part of any cell culture experiment [18].

Selenium has long been known for its toxicity. However, the toxicity of Se is determined by its molecular structure. Organic forms of selenium are typically better tolerated by humans in higher 
quantities. These organic forms are also the predominant form in our daily intake, typically as selenomethionine. Inorganic sources are taken up from the soil by plants and converted to organic forms e.g., selenomethionine. Adequate availability of Se maximizes the expression and activities of Se-dependent proteins and enzymes. Many of these play an important role in the antioxidant system. This system is thought to protect cells and tissues against oxidants that are formed from cellular processes as well as xenobiotic metabolism. It is therefore hypothesized that Se supplementation can protect against the initiation of cancer. However, conclusive evidence of a correlation between high Se intake and decreased cancer incidence is still lacking. It is more likely that many populations are adequate in selenium with a balanced diet and multivitamin supplements (including Se). Higher than adequate intake of Se will not further increase Se-dependent antioxidant enzymes. Therefore, it is unlikely that high Se intake can protect against the initiation of cancer through this mechanism. Populations that suffer from Se deficiency may benefit from Se supplementation for the prevention of cancer. It has been estimated that $25 \%$ of the world's population is sub-clinically Se-deficient [202]. Meaning that $\approx 25 \%$ of the population is Se-deficient without clinically observed adverse effects. In this sub-population, maximum Se-dependent antioxidant activities will not be achieved, suggesting that this group may have an increased risk for the development of health issues, including cancer [113] as well as cardiovascular disease $[203,204]$. Potentially, this could be prevented by supplementation with Se.

Redox-active selenium compounds, in supranutritional doses, can form reactive oxygen species (ROS). Selenium-dependent oxidation of thiols can directly result in the formation of superoxide. This will be dismuted by superoxide dismutases, forming hydrogen peroxide, which in the presence of ferrous iron generates hydroxyl radical. These ROS contribute to the damage of essential subcellular organelles, thereby driving apoptosis and necrosis in cells and tissues. These properties of Se are also suggested to prevent further progression of cancer. Transformed cells have a higher steady-state level of ROS compared to their normal cell equivalent. Therefore, the addition of redox-active Se can damage cancer cells, because cancer cells lack sufficient reducing capacity to detoxify the oxidants formed [133,157-160]. Normal cells have a relatively greater reducing capacity and will survive the challenge of redox-active Se. In addition to redox-active forms of Se, organic selenium, e.g., seleno-L-methionine (SLM), is also used for cancer treatment. It has been proposed that organic forms of Se change the vascularity of the tumor resulting in better drug delivery. The use of high doses of SLM as an adjuvant to chemotherapy may greatly improve the outcomes. Furthermore, the use of Se as an adjuvant to chemotherapy and radiation therapy has been shown to reduce the side-effects while not impacting the main oncological effects of chemo and radiation therapy $[176,205]$.

Author Contributions: J.M.S., G.R.B., R.G., J.C.S. and Y.Z. wrote the paper. J.M.S. created all figures for the review. All authors have read and agreed to the published version of the manuscript.

Acknowledgments: This work was supported by NIH grants R01 CA169046, P01 CA217797, and P42 ES013661. Additionally, the SLM clinical trial was supported in part by the Holden Comprehensive Cancer Center, NIH P30 CA086862, Pfizer, Sabinsa Pharmaceutical and Rock 'N' Ride Foundation.

Conflicts of Interest: Authors disclosed the following: J.M.S., R.G., J.C.S. and G.R.B.: These authors declare no conflict of interest. Y.Z.: Advisory Board: Amgen, Roche Diagnostics, Novartis, Jansen, Eisai, Exelixis, Castle Bioscience, Array, Bayer, Pfizer, Clovis, EMD Serono. As well as Institutional grant/research support from NewLink Genetics, Pfizer, Exelixis, Eisai. The content is solely the responsibility of the authors and does not represent views of the sponsors nor the National Institutes of Health.

\section{References}

1. Mills, G.C. Hemoglobin catabolism. I. Glutathione peroxidase, an erythrocyte enzyme which protects hemoglobin from oxidative breakdown. J. Biol. Chem. 1957, 229, 189-197. [PubMed]

2. Schwarz, K.; Bieri, J.G.; Briggs, G.M.; Scott, M.L. Prevention of exudative diathesis in chicks by factor 3 and selenium. Proc. Soc. Exp. Biol. Med. 1957, 95, 621-625. [CrossRef] [PubMed]

3. Schwarz, K.; Foltz, C.M. Selenium as an integral part of factor 3 against dietary necrotic liver degeneration. J. Am. Chem. Soc. 1957, 79, 3292-3293. [CrossRef] 
4. Flohe, L.; Gunzler, W.A.; Schock, H.H. Glutathione peroxidase: A selenoenzyme. FEBS Lett. 1973, 32, $132-134$. [CrossRef]

5. Kraus, R.J.; Foster, S.J.; Ganther, H.E. Identification of selenocysteine in glutathione peroxidase by mass spectroscopy. Biochemistry 1983, 22, 5853-5858. [CrossRef]

6. Medicine, I.O. Dietary Reference Intakes for Vitamin C, Vitamin E, Selenium, and Carotenoids; The National Academies Press: Washington, DC, USA, 2000; p. 528.

7. Xia, Y.; Hill, K.E.; Li, P.; Xu, J.; Zhou, D.; Motley, A.K.; Wang, L.; Byrne, D.W.; Burk, R.F. Optimization of selenoprotein $\mathrm{P}$ and other plasma selenium biomarkers for the assessment of the selenium nutritional requirement: A placebo-controlled, double-blind study of selenomethionine supplementation in selenium-deficient Chinese subjects. Am. J. Clin. Nutr. 2010, 92, 525-531. [CrossRef]

8. Hurst, R.; Armah, C.N.; Dainty, J.R.; Hart, D.J.; Teucher, B.; Goldson, A.J.; Broadley, M.R.; Motley, A.K.; Fairweather-Tait, S.J. Establishing optimal selenium status: Results of a randomized, double-blind, placebo-controlled trial. Am. J. Clin. Nutr. 2010, 91, 923-931. [CrossRef]

9. Burk, R.F. Effects of chemical form of selenium on plasma biomarkers in a high-dose human supplementation trial. Cancer Epidemiol. Biomark. Prev. 2006, 15, 804-810. [CrossRef]

10. Vinceti, M.; Filippini, T.; Del Giovane, C.; Dennert, G.; Zwahlen, M.; Brinkman, M.; Zeegers, M.P.; Horneber, M.; D’Amico, R.; Crespi, C.M. Selenium for preventing cancer. Cochrane Database Syst. Rev. 2018, 1. [CrossRef]

11. Fakih, M.G.; Pendyala, L.; Smith, P.F.; Creaven, P.J.; Reid, M.E.; Badmaev, V.; Azrak, R.G.; Prey, J.D.; Lawrence, D.; Rustum, Y.M. A phase I and pharmacokinetic study of fixed-dose selenomethionine and irinotecan in solid tumors. Clin. Cancer Res. 2006, 12, 1237-1244. [CrossRef]

12. Ip, C.; Thompson, H.J.; Zhu, Z.; Ganther, H.E. In vitro and in vivo studies of methylseleninic acid: Evidence that a monomethylated selenium metabolite is critical for cancer chemoprevention. Cancer Res. 2000, 60, 2882-2886. [PubMed]

13. Letavayova, L.; Vlckova, V.; Brozmanova, J. Selenium: From cancer prevention to DNA damage. Toxicology 2006, 227, 1-14. [CrossRef] [PubMed]

14. Drake, E.N. Cancer chemoprevention: Selenium as a prooxidant, not an antioxidant. Med. Hypotheses 2006, 67, 318-322. [CrossRef] [PubMed]

15. Speier, C.; Baker, S.S.; Newburger, P.E. Relationships between in vitro selenium supply, glutathione peroxidase activity, and phagocytic function in the HL-60 human myeloid cell line. J. Biol. Chem. 1985, 260, 8951-8955. [PubMed]

16. Baker, R.D., Jr.; Baker, S.S.; Rao, R. Selenium deficiency in tissue culture: Implications for oxidative metabolism. J. Pediatr. Gastroenterol. Nutr. 1998, 27, 387-392. [CrossRef] [PubMed]

17. Leist, M.; Raab, B.; Maurer, S.; Rösick, U.; Brigelius-Flohé, R. Conventional cell culture media do not adequately supply cells with antioxidants and thus facilitate peroxide-induced genotoxicity. Free Radic. Biol. Med. 1996, 21, 297-306. [CrossRef]

18. Stolwijk, J.M.; Falls-Hubert, K.C.; Searby, C.; Wagner, B.A.; Buettner, G.R. Simultaneous detection of the enzyme activities of GPx1 and GPx4 guide optimization of selenium in cell biological experiments. Redox Biol. 2020, 32. [CrossRef]

19. Avery, J.C.; Hoffmann, P.R. Selenium, selenoproteins, and immunity. Nutrients 2018, 10, 1203. [CrossRef]

20. Sevanian, A.; Muakkassah-Kelly, S.F.; Montestruque, S. The influence of phospholipase A2 and glutathione peroxidase on the elimination of membrane lipid peroxides. Arch. Biochem. Biophys. 1983, 223, 441-452. [CrossRef]

21. Weitzel, F.; Ursini, F.; Wendel, A. Phospholipid hydroperoxide glutathione peroxidase in various mouse organs during selenium deficiency and repletion. Biochim. Biophys. Acta (BBA)—Gen. Subj. 1990, 1036, 88-94. [CrossRef]

22. Maiorino, M.; Gregolin, C.; Ursini, F. Phospholipid hydroperoxide glutathione peroxidase. Methods Enzym. 1990, 186, 448-457. [CrossRef]

23. Martinez, J.I.; Garcia, R.D.; Galarza, A.M. The kinetic mechanism of glutathione peroxidase from human platelets. Thromb Res. 1982, 27, 197-203. [CrossRef]

24. Gladyshev, V.N.; Factor, V.M.; Housseau, F.; Hatfield, D.L. Contrasting patterns of regulation of the antioxidant selenoproteins, thioredoxin reductase, and glutathione peroxidase, in cancer cells. Biochem. Biophys. Res. Commun. 1998, 251, 488-493. [CrossRef] [PubMed] 
25. Bedard, K.; Krause, K.H. The NOX family of ROS-generating NADPH oxidases: Physiology and pathophysiology. Physiol. Rev. 2007, 87, 245-313. [CrossRef] [PubMed]

26. Lubos, E.; Loscalzo, J.; Handy, D.E. Glutathione peroxidase-1 in health and disease: From molecular mechanisms to therapeutic opportunities. Antioxid. Redox Signal. 2011, 15, 1957-1997. [CrossRef]

27. Cheng, W.H.; Ho, Y.S.; Ross, D.A.; Valentine, B.A.; Combs, G.F.; Lei, X.G. Cellular glutathione peroxidase knockout mice express normal levels of selenium-dependent plasma and phospholipid hydroperoxide glutathione peroxidases in various tissues. J. Nutr. 1997, 127, 1445-1450. [CrossRef]

28. Lei, X.G.; Cheng, W.H.; McClung, J.P. Metabolic regulation and function of glutathione peroxidase-1. Annu. Rev. Nutr. 2007, 27, 41-61. [CrossRef]

29. Cheng, W.; Fu, Y.X.; Porres, J.M.; Ross, D.A.; Lei, X.G. Selenium-dependent cellular glutathione peroxidase protects mice against a pro-oxidant-induced oxidation of NADPH, NADH, lipids, and protein. FASEB J. 1999, 13, 1467-1475. [CrossRef]

30. Esworthy, R.S.; Baker, M.A.; Chu, F.F. Expression of selenium-dependent glutathione peroxidase in human breast tumor cell lines. Cancer Res. 1995, 55, 957-962.

31. Jee, C.D.; Kim, M.A.; Jung, E.J.; Kim, J.; Kim, W.H. Identification of genes epigenetically silenced by CpG methylation in human gastric carcinoma. Eur. J. Cancer 2009, 45, 1282-1293. [CrossRef]

32. De Haan, J.B.; Bladier, C.; Griffiths, P.; Kelner, M.; O’Shea, R.D.; Cheung, N.S.; Bronson, R.T.; Silvestro, M.J.; Wild, S.; Zheng, S.S.; et al. Mice with a homozygous null mutation for the most abundant glutathione peroxidase, Gpx1, show increased susceptibility to the oxidative stress-inducing agents paraquat and hydrogen peroxide. J. Biol. Chem. 1998, 273, 22528-22536. [CrossRef]

33. Baliga, M.S.; Wang, H.; Zhuo, P.; Schwartz, J.L.; Diamond, A.M. Selenium and GPx-1 overexpression protect mammalian cells against UV-induced DNA damage. Biol. Trace Elem. Res. 2007, 115, 227-242. [CrossRef]

34. Throm, S.L.; Klemsz, M.J. PU. 1 regulates glutathione peroxidase expression in neutrophils. J. Leukoc Biol. 2003, 74, 111-117. [CrossRef]

35. Borras, C.; Gambini, J.; Gomez-Cabrera, M.C.; Sastre, J.; Pallardo, F.V.; Mann, G.E.; Vina, J. 17beta-oestradiol up-regulates longevity-related, antioxidant enzyme expression via the ERK1 and ERK2[MAPK]/NFkappaB cascade. Aging Cell 2005, 4, 113-118. [CrossRef] [PubMed]

36. Vina, J.; Borras, C.; Gomez-Cabrera, M.C.; Orr, W.C. Part of the series: From dietary antioxidants to regulators in cellular signalling and gene expression. Role of reactive oxygen species and (phyto)oestrogens in the modulation of adaptive response to stress. Free Radic. Res. 2006, 40, 111-119. [CrossRef] [PubMed]

37. Tan, M.; Li, S.; Swaroop, M.; Guan, K.; Oberley, L.W.; Sun, Y. Transcriptional activation of the human glutathione peroxidase promoter by p53. J. Biol. Chem. 1999, 274, 12061-12066. [CrossRef] [PubMed]

38. Brigelius-Flohé, R.; Kipp, A. Glutathione peroxidases in different stages of carcinogenesis. Biochim. Biophys. Acta (BBA)—Gen. Subj. 2009, 1790, 1555-1568. [CrossRef]

39. Lee, W.P.; Lee, C.L.; Lin, H.C. Glutathione S-transferase and glutathione peroxidase are essential in the early stage of adriamycin resistance before P-glycoprotein overexpression in HOB1 lymphoma cells. Cancer Chemother. Pharm. 1996, 38, 45-51. [CrossRef]

40. Lu, Y.P.; Lou, Y.R.; Yen, P.; Newmark, H.L.; Mirochnitchenko, O.I.; Inouye, M.; Huang, M.T. Enhanced skin carcinogenesis in transgenic mice with high expression of glutathione peroxidase or both glutathione peroxidase and superoxide dismutase. Cancer Res. 1997, 57, 1468-1474.

41. Ho, J.C.; Chan-Yeung, M.; Ho, S.P.; Mak, J.C.; Ip, M.S.; Ooi, G.C.; Wong, M.P.; Tsang, K.W.; Lam, W.K. Disturbance of systemic antioxidant profile in nonsmall cell lung carcinoma. Eur. Respir. J. 2007, 29, 273-278. [CrossRef]

42. Florian, S.; Krehl, S.; Loewinger, M.; Kipp, A.; Banning, A.; Esworthy, S.; Chu, F.-F.; Brigelius-Flohé, R. Loss of GPx2 increases apoptosis, mitosis, and GPx1 expression in the intestine of mice. Free Radic. Biol. Med. 2010, 49, 1694-1702. [CrossRef] [PubMed]

43. Emmink, B.L.; Laoukili, J.; Kipp, A.P.; Koster, J.; Govaert, K.M.; Fatrai, S.; Verheem, A.; Steller, E.J.A.; Brigelius-Flohé, R.; Jimenez, C.R.; et al. GPx2 Suppression of H2O2 stress links the formation of differentiated tumor mass to metastatic capacity in colorectal cancer. Cancer Res. 2014, 74, 6717. [CrossRef] [PubMed]

44. Koyama, H.; Omura, K.; Ejima, A.; Kasanuma, Y.; Watanabe, C.; Satoh, H. Separation of selenium-containing proteins in human and mouse plasma using tandem high-performance liquid chromatography columns coupled with inductively coupled plasma-mass spectrometry. Anal. Biochem. 1999, 267, 84-91. [CrossRef] 
45. Hoffmann, P.R.; Hoge, S.C.; Li, P.A.; Hoffmann, F.W.; Hashimoto, A.C.; Berry, M.J. The selenoproteome exhibits widely varying, tissue-specific dependence on selenoprotein P for selenium supply. Nucleic Acids Res. 2007, 35, 3963-3973. [CrossRef]

46. Smith, C.V.; Jones, D.P.; Guenthner, T.M.; Lash, L.H.; Lauterburg, B.H. Compartmentation of glutathione: Implications for the study of toxicity and disease. Toxicol. Appl. Pharmacol. 1996, 140, 1-12. [CrossRef]

47. Jones, D.P.; Carlson, J.L.; Samiec, P.S.; Sternberg, P., Jr.; Mody, V.C., Jr.; Reed, R.L.; Brown, L.A. Glutathione measurement in human plasma. Evaluation of sample collection, storage and derivatization conditions for analysis of dansyl derivatives by HPLC. Clin. Chim. Acta 1998, 275, 175-184. [CrossRef]

48. Stenzel, J.D.; Welty, S.E.; Benzick, A.E.; Smith, E.O.; Smith, C.V.; Hansen, T.N. Hyperoxic lung injury in Fischer-344 and Sprague-Dawley rats in vivo. Free Radic. Biol. Med. 1993, 14, 531-539. [CrossRef]

49. Ottaviano, F.G.; Tang, S.-S.; Handy, D.E.; Loscalzo, J. Regulation of the extracellular antioxidant selenoprotein plasma glutathione peroxidase (GPx-3) in mammalian cells. Mol. Cell. Biochem. 2009, 327, 111-126. [CrossRef]

50. Ren, B.; Huang, W.; Akesson, B.; Ladenstein, R. The crystal structure of seleno-glutathione peroxidase from human plasma at 2.9 A resolution. J. Mol. Biol. 1997, 268, 869-885. [CrossRef]

51. Freedman, J.E.; Frei, B.; Welch, G.N.; Loscalzo, J. Glutathione peroxidase potentiates the inhibition of platelet function by S-nitrosothiols. J. Clin. Investig. 1995, 96, 394-400. [CrossRef]

52. Barrett, C.W.; Ning, W.; Chen, X.; Smith, J.J.; Washington, M.K.; Hill, K.E.; Coburn, L.A.; Peek, R.M.; Chaturvedi, R.; Wilson, K.T.; et al. Tumor suppressor function of the plasma glutathione peroxidase gpx3 in colitis-associated carcinoma. Cancer Res. 2013, 73, 1245-1255. [CrossRef] [PubMed]

53. Conrad, M.; Schneider, M.; Seiler, A.; Bornkamm, G.W. Physiological role of phospholipid hydroperoxide glutathione peroxidase in mammals. Biol. Chem. 2007, 388, 1019-1025. [CrossRef] [PubMed]

54. Yant, L.J.; Ran, Q.; Rao, L.; Van Remmen, H.; Shibatani, T.; Belter, J.G.; Motta, L.; Richardson, A.; Prolla, T.A. The selenoprotein GPX4 is essential for mouse development and protects from radiation and oxidative damage insults. Free Radic. Biol. Med. 2003, 34, 496-502. [CrossRef]

55. Ursini, F.; Heim, S.; Kiess, M.; Maiorino, M.; Roveri, A.; Wissing, J.; Flohe, L. Dual function of the selenoprotein PHGPx during sperm maturation. Science 1999, 285, 1393-1396. [CrossRef]

56. Dixon, S.J.; Lemberg, K.M.; Lamprecht, M.R.; Skouta, R.; Zaitsev, E.M.; Gleason, C.E.; Patel, D.N.; Bauer, A.J.; Cantley, A.M.; Yang, W.S.; et al. Ferroptosis: An iron-dependent form of nonapoptotic cell death. Cell 2012, 149, 1060-1072. [CrossRef]

57. Yang, W.S.; SriRamaratnam, R.; Welsch, M.E.; Shimada, K.; Skouta, R.; Viswanathan, V.S.; Cheah, J.H.; Clemons, P.A.; Shamji, A.F.; Clish, C.B.; et al. Regulation of ferroptotic cancer cell death by GPX4. Cell 2014, 156, 317-331. [CrossRef]

58. Buettner, G.R. The Pecking Order of Free Radicals and Antioxidants: Lipid Peroxidation, $\alpha$-Tocopherol, and Ascorbate. Arch. Biochem. Biophys. 1993, 300, 535-543. [CrossRef]

59. Qian, S.Y.; Wang, H.P.; Schafer, F.Q.; Buettner, G.R. EPR detection of lipid-derived free radicals from PUFA, LDL, and cell oxidations. Free Radic. Biol. Med. 2000, 29, 568-579. [CrossRef]

60. Girotti, A.W. Mechanisms of lipid peroxidation. J. Free Radic. Biol. Med. 1985, 1, 87-95. [CrossRef]

61. Wilcox, A.L.; Marnett, L.J. Polyunsaturated fatty acid alkoxyl radicals exist as carbon-centered epoxyallylic radicals: A key step in hydroperoxide-amplified lipid peroxidation. Chem. Res. Toxicol. 1993, 6, 413-416. [CrossRef]

62. Wagner, B.A.; Buettner, G.R.; Burns, C.P. Vitamin E slows the rate of free radical-mediated lipid peroxidation in cells. Arch. Biochem. Biophys. 1996, 334, 261-267. [CrossRef] [PubMed]

63. Zhong, H.; Yin, H. Role of lipid peroxidation derived 4-hydroxynonenal (4-HNE) in cancer: Focusing on mitochondria. Redox Biol. 2015, 4, 193-199. [CrossRef] [PubMed]

64. Cheeseman, K.H. Mechanisms and effects of lipid peroxidation. Mol. Asp. Med. 1993, 14, 191-197. [CrossRef]

65. Wang, H.P.; Schafer, F.Q.; Goswami, P.C.; Oberley, L.W.; Buettner, G.R. Phospholipid hydroperoxide glutathione peroxidase induces a delay in G1 of the cell cycle. Free Radic. Res. 2003, 37, 621-630. [CrossRef]

66. Wang, H.P.; Qian, S.Y.; Schafer, F.Q.; Domann, F.E.; Oberley, L.W.; Buettner, G.R. Phospholipid hydroperoxide glutathione peroxidase protects against singlet oxygen-induced cell damage of photodynamic therapy. Free Radic. Biol. Med. 2001, 30, 825-835. [CrossRef]

67. Mustacich, D.; Powis, G. Thioredoxin reductase. Biochem. J. 2000, 346, 1-8. [CrossRef]

68. Jacob, C.; Giles, G.I.; Giles, N.M.; Sies, H. Sulfur and selenium: The role of oxidation state in protein structure and function. Angew. Chem. Int. Ed. Engl. 2003, 42, 4742-4758. [CrossRef] 
69. Ng, C.F.; Schafer, F.Q.; Buettner, G.R.; Rodgers, V.G. The rate of cellular hydrogen peroxide removal shows dependency on GSH: Mathematical insight into in vivo H2O2 and GPx concentrations. Free Radic. Res. 2007, 41, 1201-1211. [CrossRef]

70. Rhee, S.G.; Woo, H.A.; Kil, I.S.; Bae, S.H. Peroxiredoxin functions as a peroxidase and a regulator and sensor of local peroxides. J. Biol. Chem. 2012, 287, 4403-4410. [CrossRef]

71. Kolberg, M.; Strand, K.R.; Graff, P.; Andersson, K.K. Structure, function, and mechanism of ribonucleotide reductases. Biochim. Biophys. Acta 2004, 1699, 1-34. [CrossRef]

72. Wei, S.J.; Botero, A.; Hirota, K.; Bradbury, C.M.; Markovina, S.; Laszlo, A.; Spitz, D.R.; Goswami, P.C.; Yodoi, J.; Gius, D. Thioredoxin nuclear translocation and interaction with redox factor-1 activates the activator protein-1 transcription factor in response to ionizing radiation. Cancer Res. 2000, 60, 6688-6695. [PubMed]

73. Tsuji, P.A.; Carlson, B.A.; Anderson, C.B.; Seifried, H.E.; Hatfield, D.L.; Howard, M.T. Dietary Selenium Levels Affect Selenoprotein Expression and Support the Interferon-gamma and IL-6 Immune Response Pathways in Mice. Nutrients 2015, 7, 6529-6549. [CrossRef] [PubMed]

74. Lu, J.; Holmgren, A. Selenoproteins. J. Biol. Chem. 2009, 284, 723-727. [CrossRef] [PubMed]

75. Jakupoglu, C.; Przemeck, G.K.; Schneider, M.; Moreno, S.G.; Mayr, N.; Hatzopoulos, A.K.; De Angelis, M.H.; Wurst, W.; Bornkamm, G.W.; Brielmeier, M.; et al. Cytoplasmic thioredoxin reductase is essential for embryogenesis but dispensable for cardiac development. Mol. Cell. Biol. 2005, 25, 1980-1988. [CrossRef] [PubMed]

76. Lu, J.; Chew, E.H.; Holmgren, A. Targeting thioredoxin reductase is a basis for cancer therapy by arsenic trioxide. Proc. Natl. Acad. Sci. USA 2007, 104, 12288-12293. [CrossRef]

77. Marzano, C.; Gandin, V.; Folda, A.; Scutari, G.; Bindoli, A.; Rigobello, M.P. Inhibition of thioredoxin reductase by auranofin induces apoptosis in cisplatin-resistant human ovarian cancer cells. Free Radic. Biol. Med. 2007, 42, 872-881. [CrossRef]

78. Nguyen, P.; Awwad, R.T.; Smart, D.D.K.; Spitz, D.R.; Gius, D. Thioredoxin reductase as a novel molecular target for cancer therapy. Cancer Lett. 2006, 236, 164-174. [CrossRef]

79. Warburg, O. On the origin of cancer cells. Science 1956, 123, 309-314. [CrossRef]

80. Holmgren, A.; Bjornstedt, M. Thioredoxin and thioredoxin reductase. Methods Enzym. 1995. [CrossRef]

81. Nakamura, H.; Nakamura, K.; Yodoi, J. Redox regulation of cellular activation. Annu. Rev. Immunol. 1997, 15, 351-369. [CrossRef]

82. Lei, H.; Wang, G.; Zhang, J.; Han, Q. Inhibiting TrxR suppresses liver cancer by inducing apoptosis and eliciting potent antitumor immunity. Oncol. Rep. 2018, 40, 3447-3457. [CrossRef] [PubMed]

83. Lu, J.; Papp, L.V.; Fang, J.; Rodriguez-Nieto, S.; Zhivotovsky, B.; Holmgren, A. Inhibition of mammalian thioredoxin reductase by some flavonoids: Implications for myricetin and quercetin anticancer activity. Cancer Res. 2006, 66, 4410-4418. [CrossRef] [PubMed]

84. Bianco, A.C.; Salvatore, D.; Gereben, B.; Berry, M.J.; Larsen, P.R. Biochemistry, cellular and molecular biology, and physiological roles of the iodothyronine selenodeiodinases. Endocr. Rev. 2002, 23, 38-89. [CrossRef] [PubMed]

85. Gross, M.; Oertel, M.; Köhrle, J. Differential selenium-dependent expression of type I 5'-deiodinase and glutathione peroxidase in the porcine epithelial kidney cell line LLC-PK 1. Biochem. J. 1995, 306, 851-856. [CrossRef] [PubMed]

86. Schomburg, L.; Schweizer, U. Hierarchical regulation of selenoprotein expression and sex-specific effects of selenium. Biochim. Biophys. Acta 2009, 1790, 1453-1462. [CrossRef] [PubMed]

87. Vanderpas, J. Nutritional epidemiology and thyroid hormone metabolism. Annu. Rev. Nutr. 2006, 26, 293-322. [CrossRef]

88. Casula, S.; Bianco, A.C. Thyroid hormone deiodinases and cancer. Front. Endocrinol. (Lausanne) 2012, 3, 74. [CrossRef]

89. Kim, H.Y.; Gladyshev, V.N. Methionine sulfoxide reductases: Selenoprotein forms and roles in antioxidant protein repair in mammals. Biochem. J. 2007, 407, 321-329. [CrossRef]

90. Fomenko, D.E.; Novoselov, S.V.; Natarajan, S.K.; Lee, B.C.; Koc, A.; Carlson, B.A.; Lee, T.H.; Kim, H.Y.; Hatfield, D.L.; Gladyshev, V.N. MsrB1 (methionine-R-sulfoxide reductase 1) knock-out mice: Roles of MsrB1 in redox regulation and identification of a novel selenoprotein form. J. Biol. Chem. 2009, 284, 5986-5993. [CrossRef] 
91. He, Q.; Li, H.; Meng, F.; Sun, X.; Feng, X.; Chen, J.; Li, L.; Liu, J. Methionine sulfoxide reductase B1 regulates hepatocellular carcinoma cell proliferation and invasion via the mitogen-activated protein kinase pathway and epithelial-mesenchymal transition. Oxid. Med. Cell. Longev. 2018, 2018, 5287971. [CrossRef]

92. Hill, K.E.; Zhou, J.; McMahan, W.J.; Motley, A.K.; Atkins, J.F.; Gesteland, R.F.; Burk, R.F. Deletion of selenoprotein P alters distribution of selenium in the mouse. J. Biol. Chem. 2003, 278, 13640-13646. [CrossRef] [PubMed]

93. Schomburg, L.; Schweizer, U.; Holtmann, B.; Flohe, L.; Sendtner, M.; Kohrle, J. Gene disruption discloses role of selenoprotein P in selenium delivery to target tissues. Biochem. J. 2003, 370, 397-402. [CrossRef]

94. Schweizer, U.; Streckfuss, F.; Pelt, P.; Carlson, B.A.; Hatfield, D.L.; Kohrle, J.; Schomburg, L. Hepatically derived selenoprotein $\mathrm{P}$ is a key factor for kidney but not for brain selenium supply. Biochem. J. 2005, 386, 221-226. [CrossRef]

95. Valentine, W.M.; Abel, T.W.; Hill, K.E.; Austin, L.M.; Burk, R.F. Neurodegeneration in mice resulting from loss of functional selenoprotein $\mathrm{P}$ or its receptor apolipoprotein E receptor 2. J. Neuropathol. Exp. Neurol. 2008, 67, 68-77. [CrossRef] [PubMed]

96. Olson, G.E.; Winfrey, V.P.; Nagdas, S.K.; Hill, K.E.; Burk, R.F. Apolipoprotein E receptor-2 (ApoER2) mediates selenium uptake from selenoprotein P by the mouse testis. J. Biol. Chem. 2007, 282, 12290-12297. [CrossRef] [PubMed]

97. Olson, G.E.; Winfrey, V.P.; Hill, K.E.; Burk, R.F. Megalin mediates selenoprotein P uptake by kidney proximal tubule epithelial cells. J. Biol. Chem. 2008, 283, 6854-6860. [CrossRef]

98. Meyer, H.A.; Endermann, T.; Stephan, C.; Stoedter, M.; Behrends, T.; Wolff, I.; Jung, K.; Schomburg, L. Selenoprotein P Status Correlates to Cancer-Specific Mortality in Renal Cancer Patients. PLoS ONE 2012, 7, e46644. [CrossRef]

99. Renko, K.; Hofmann, P.J.; Stoedter, M.; Hollenbach, B.; Behrends, T.; Kohrle, J.; Schweizer, U.; Schomburg, L. Down-regulation of the hepatic selenoprotein biosynthesis machinery impairs selenium metabolism during the acute phase response in mice. Faseb J. 2009, 23, 1758-1765. [CrossRef]

100. Nichol, C.; Herdman, J.; Sattar, N.; O’Dwyer, P.J.; St, J.O.R.D.; Littlejohn, D.; Fell, G. Changes in the concentrations of plasma selenium and selenoproteins after minor elective surgery: Further evidence for a negative acute phase response? Clin. Chem. 1998, 44, 1764-1766. [CrossRef]

101. Meplan, C.; Crosley, L.K.; Nicol, F.; Beckett, G.J.; Howie, A.F.; Hill, K.E.; Horgan, G.; Mathers, J.C.; Arthur, J.R.; Hesketh, J.E. Genetic polymorphisms in the human selenoprotein P gene determine the response of selenoprotein markers to selenium supplementation in a gender-specific manner (the SELGEN study). Faseb J. 2007, 21, 3063-3074. [CrossRef]

102. Méplan, C.; Nicol, F.; Burtle, B.T.; Crosley, L.K.; Arthur, J.R.; Mathers, J.C.; Hesketh, J.E. Relative Abundance of Selenoprotein P Isoforms in Human Plasma Depends on Genotype, Se Intake, and Cancer Status. Antioxid. Redox Signal. 2009, 11, 2631-2640. [CrossRef] [PubMed]

103. Kraus, R.J.; Prohaska, J.R.; Ganther, H.E. Oxidized forms of ovine erythrocyte glutathione peroxidase. Cyanide inhibition of a 4-glutathione:4-selenoenzyme. Biochim. Biophys. Acta 1980, 615, 19-26. [CrossRef]

104. Labunskyy, V.M.; Ferguson, A.D.; Fomenko, D.E.; Chelliah, Y.; Hatfield, D.L.; Gladyshev, V.N. A novel cysteine-rich domain of Sep15 mediates the interaction with UDP-glucose: Glycoprotein glucosyltransferase. J. Biol. Chem. 2005, 280, 37839-37845. [CrossRef] [PubMed]

105. Ferguson, A.D.; Labunskyy, V.M.; Fomenko, D.E.; Arac, D.; Chelliah, Y.; Amezcua, C.A.; Rizo, J.; Gladyshev, V.N.; Deisenhofer, J. NMR structures of the selenoproteins Sep15 and SelM reveal redox activity of a new thioredoxin-like family. J. Biol. Chem. 2006, 281, 3536-3543. [CrossRef]

106. Labunskyy, V.M.; Hatfield, D.L.; Gladyshev, V.N. The Sep15 protein family: Roles in disulfide bond formation and quality control in the endoplasmic reticulum. IUBMB Life 2007, 59, 1-5. [CrossRef]

107. Jiang, H.; Shi, Q.-Q.; Ge, L.-Y.; Zhuang, Q.-F.; Xue, D.; Xu, H.-Y.; He, X.-Z. Selenoprotein M stimulates the proliferative and metastatic capacities of renal cell carcinoma through activating the PI3K/AKT/mTOR pathway. Cancer Med. 2019, 8, 4836-4844. [CrossRef]

108. Tsuji, P.A.; Naranjo-Suarez, S.; Carlson, B.A.; Tobe, R.; Yoo, M.-H.; Davis, C.D. Deficiency in the 15 kDa selenoprotein inhibits human colon cancer cell growth. Nutrients 2011,3, 805-817. [CrossRef]

109. Jaspers, I.; Zhang, W.; Brighton, L.E.; Carson, J.L.; Styblo, M.; Beck, M.A. Selenium deficiency alters epithelial cell morphology and responses to influenza. Free Radic. Biol. Med. 2007, 42, 1826-1837. [CrossRef] 
110. Ebert, R.; Ulmer, M.; Zeck, S.; Meissner-Weigl, J.; Schneider, D.; Stopper, H.; Schupp, N.; Kassem, M.; Jakob, F. Selenium supplementation restores the antioxidative capacity and prevents cell damage in bone marrow stromal cells in vitro. Stem. Cells 2006, 24, 1226-1235. [CrossRef] [PubMed]

111. Saito, Y.; Yoshida, Y.; Akazawa, T.; Takahashi, K.; Niki, E. Cell death caused by selenium deficiency and protective effect of antioxidants. J. Biol. Chem. 2003. [CrossRef]

112. Prabhu, K.S.; Zamamiri-Davis, F.; Stewart, J.B.; Thompson, J.T.; Sordillo, L.M.; Reddy, C.C. Selenium deficiency increases the expression of inducible nitric oxide synthase in RAW 264.7 macrophages: Role of nuclear factor- $\mathrm{KB}$ in up-regulation. Biochem. J. 2002, 366, 203-209. [CrossRef] [PubMed]

113. Kristal, A.R.; Darke, A.K.; Morris, J.S.; Tangen, C.M.; Goodman, P.J.; Thompson, I.M.; Meyskens, F.L., Jr.; Goodman, G.E.; Minasian, L.M.; Parnes, H.L.; et al. Baseline selenium status and effects of selenium and vitamin e supplementation on prostate cancer risk. JNCI J. Natl. Cancer Inst. 2014, 106. [CrossRef] [PubMed]

114. Klein, E.A.; Thompson, I.M.; Tangen, C.M.; Crowley, J.J.; Lucia, M.S.; Goodman, P.J.; Minasian, L.M.; Ford, L.G.; Parnes, H.L.; Gaziano, J.M.; et al. Vitamin E and the risk of prostate cancer: The Selenium and Vitamin E Cancer Prevention Trial (SELECT). JAMA 2011, 306, 1549-1556. [CrossRef] [PubMed]

115. Hatfield, D.L.; Gladyshev, V.N. The outcome of Selenium and Vitamin E Cancer Prevention Trial (SELECT) reveals the need for better understanding of selenium biology. Mol. Interv. 2009, 9, 18-21. [CrossRef]

116. Muecke, R.; Schomburg, L.; Buentzel, J.; Kisters, K.; Micke, O. Selenium or no selenium-That is the question in tumor patients: A new controversy. Integr. Cancer Ther. 2010, 9, 136-141. [CrossRef]

117. Rayman, M.P. Food-chain selenium and human health: Emphasis on intake. Br. J. Nutr. 2008, 100, $254-268$. [CrossRef]

118. El-Bayoumy, K. The protective role of selenium on genetic damage and on cancer. Mutat. Res. 2001, 475, 123-139. [CrossRef]

119. Ip, C.; Lisk, D.J. Enrichment of selenium in allium vegetables for cancer prevention. Carcinogenesis 1994, 15, 1881-1885. [CrossRef]

120. Ip, C.; Lisk, D.J. Modulation of phase I and phase II xenobiotic-metabolizing enzymes by selenium-enriched garlic in rats. Nutr. Cancer 1997, 28, 184-188. [CrossRef]

121. Spivack, S.D.; Hurteau, G.J.; Fasco, M.J.; Kaminsky, L.S. Phase I and II Carcinogen Metabolism Gene Expression in Human Lung Tissue and Tumors. Clin. Cancer Res. 2003, 9, 6002.

122. Smith, L.E.; Denissenko, M.F.; Bennett, W.P.; Li, H.; Amin, S.; Tang, M.S.; Pfeifer, G.P. Targeting of Lung Cancer Mutational Hotspots by Polycyclic Aromatic Hydrocarbons. JNCI J. Natl. Cancer Inst. 2000, 92, 803-811. [CrossRef] [PubMed]

123. Chen, J.X.; Zheng, Y.; West, M.; Tang, M.-S. Carcinogens preferentially bind at methylated CpG in the p53 mutational hot spots. Cancer Res. 1998, 58, 2070. [PubMed]

124. Clark, L.C. Effects of selenium supplementation for cancer prevention in patients with carcinoma of the skin. JAMA 1996, 276, 1957. [CrossRef]

125. Marshall, J.R.; Tangen, C.M.; Sakr, W.A.; Wood, D.P.; Berry, D.L.; Klein, E.A.; Lippman, S.M.; Parnes, H.L.; Alberts, D.S.; Jarrard, D.F.; et al. Phase III trial of selenium to prevent prostate cancer in men with high-grade prostatic intraepithelial neoplasia: SWOG S9917. Cancer Prev. Res. 2011, 4, 1761-1769. [CrossRef]

126. Karp, D.D.; Lee, S.J.; Keller, S.M.; Wright, G.S.; Aisner, S.; Belinsky, S.A.; Johnson, D.H.; Johnston, M.R.; Goodman, G.; Clamon, G.; et al. Randomized, double-blind, placebo-controlled, phase III chemoprevention trial of selenium supplementation in patients with resected stage I non-small-cell lung cancer: ECOG 5597. J. Clin. Oncol. 2013, 31, 4179-4187. [CrossRef]

127. Ip, C.; Ganther, H.E. Activity of methylated forms of selenium in cancer prevention. Cancer Res. 1990, 50, 1206. [PubMed]

128. Jung, H.J.; Kim, H.L.; Seo, Y.R. Enhanced redox factor 1 (REF1)-modulated p53 stabilization and JNK1 dissociation in response to selenomethionine. Anticancer Res. 2013, 33, 3645-3651.

129. Fischer, J.L.; Lancia, J.K.; Mathur, A.; Smith, M.L. Selenium protection from DNA damage involves a Ref1/p53/Brca1 protein complex. Anticancer Res. 2006, 26, 899-904.

130. Seo, Y.R.; Sweeney, C.; Smith, M.L. Selenomethionine induction of DNA repair response in human fibroblasts. Oncogene 2002, 21, 3663-3669. [CrossRef]

131. Tosatto, S.C.E.; Bosello, V.; Fogolari, F.; Mauri, P.; Roveri, A.; Toppo, S.; Flohé, L.; Ursini, F.; Maiorino, M. The catalytic site of glutathione peroxidases. Antioxid. Redox Signal. 2008, 10, 1515-1526. [CrossRef] 
132. Poole, L.B. The basics of thiols and cysteines in redox biology and chemistry. Free Radic. Biol. Med. 2015, 80, 148-157. [CrossRef] [PubMed]

133. Misra, S.; Boylan, M.; Selvam, A.; Spallholz, J.; Björnstedt, M. Redox-active selenium compounds—From toxicity and cell death to cancer treatment. Nutrients 2015, 7, 3536-3556. [CrossRef]

134. Labunskyy, V.M.; Hatfield, D.L.; Gladyshev, V.N. Selenoproteins: Molecular pathways and physiological roles. Physiol. Rev. 2014, 94, 739-777. [CrossRef] [PubMed]

135. Moghadaszadeh, B.; Beggs, A.H. Selenoproteins and their impact on human health through diverse physiological pathways. Physiology (Bethesda) 2006, 21, 307-315. [CrossRef] [PubMed]

136. Gopalakrishna, R.; Gundimeda, U. Antioxidant regulation of protein kinase C in cancer prevention. J. Nutr. 2002, 132, 3819s-3823s. [CrossRef]

137. Ammar, E.M.; Couri, D. Acute toxicity of sodium selenite and selenomethionine in mice after ICV or IV administration. Neurotoxicology 1981, 2, 383-386.

138. Desta, B.; Maldonado, G.; Reid, H.; Puschner, B.; Maxwell, J.; Agasan, A.; Humphreys, L.; Holt, T. Acute selenium toxicosis in polo ponies. J. Vet. Diagn. Invest. 2011, 23, 623-628. [CrossRef]

139. Ganther, H.E. Selenium metabolism, selenoproteins and mechanisms of cancer prevention: Complexities with thioredoxin reductase. Carcinogenesis 1999, 20, 1657-1666. [CrossRef]

140. Morris, J.; Crane, S. Selenium Toxicity from a misformulated dietary supplement, adverse health effects, and the temporal response in the nail biologic monitor. Nutrients 2013, 5, 1024-1057. [CrossRef]

141. Macfarquhar, J.K. Acute selenium toxicity associated with a dietary supplement. Arch. Intern. Med. 2010, 170, 256. [CrossRef]

142. Stewart, M.S.; Spallholz, J.E.; Neldner, K.H.; Pence, B.C. Selenium compounds have disparate abilities to impose oxidative stress and induce apoptosis. Free Radic. Biol. Med. 1999, 26, 42-48. [CrossRef]

143. Spallholz, J.E. On the nature of selenium toxicity and carcinostatic activity. Free Radic. Biol. Med. 1994, 17, 45-64. [CrossRef]

144. Lafin, J.T.; Sarsour, E.H.; Kalen, A.L.; Wagner, B.A.; Buettner, G.R.; Goswami, P.C. Methylseleninic acid induces lipid peroxidation and radiation sensitivity in head and neck cancer cells. Int. J. Mol. Sci. 2019, 20, 225. [CrossRef] [PubMed]

145. Seko, Y.; Imura, N. Active oxygen generation as a possible mechanism of selenium toxicity. Biomed. Env. Sci. 1997, 10, 333-339.

146. Yan, L.; Spallholz, J.E. Generation of reactive oxygen species from the reaction of selenium compounds with thiols and mammary tumor cells. Biochem. Pharmacol. 1993, 45, 429-437. [PubMed]

147. Kim, H.Y.; Gladyshev, V.N. Methionine sulfoxide reduction in mammals: Characterization of methionine-R-sulfoxide reductases. Mol. Biol. Cell 2004, 15, 1055-1064. [CrossRef]

148. Kim, I.Y.; Stadtman, T.C. Inhibition of NF-kappaB DNA binding and nitric oxide induction in human T cells and lung adenocarcinoma cells by selenite treatment. Proc. Natl. Acad. Sci. USA 1997, 94, 12904-12907. [CrossRef]

149. Spyrou, G.; Bjornstedt, M.; Kumar, S.; Holmgren, A. AP-1 DNA-binding activity is inhibited by selenite and selenodiglutathione. FEBS Lett. 1995, 368, 59-63. [CrossRef]

150. Ghosh, J. Rapid induction of apoptosis in prostate cancer cells by selenium: Reversal by metabolites of arachidonate 5-lipoxygenase. Biochem. Biophys. Res. Commun. 2004, 315, 624-635. [CrossRef]

151. Bergad, P.L.; Rathbun, W.B. Inhibition of Na, K-ATPase by sodium selenite and reversal by glutathione. Curr. Eye Res. 1986, 5, 919-923. [CrossRef]

152. Islam, F.; Watanabe, Y.; Morii, H.; Hayaishi, O. Inhibition of rat brain prostaglandin D synthase by inorganic selenocompounds. Arch. Biochem. Biophys. 1991, 289, 161-166. [CrossRef]

153. Sinha, R.; Medina, D. Inhibition of cdk2 kinase activity by methylselenocysteine in synchronized mouse mammary epithelial tumor cells. Carcinogenesis 1997, 18, 1541-1547. [CrossRef] [PubMed]

154. Gopalakrishna, R.; Chen, Z.H.; Gundimeda, U. Selenocompounds induce a redox modulation of protein kinase $\mathrm{C}$ in the cell, compartmentally independent from cytosolic glutathione: Its role in inhibition of tumor promotion. Arch. Biochem. Biophys. 1997, 348, 37-48. [CrossRef] [PubMed]

155. Park, H.S.; Huh, S.H.; Kim, Y.; Shim, J.; Lee, S.H.; Park, I.S.; Jung, Y.K.; Kim, I.Y.; Choi, E.J. Selenite negatively regulates caspase-3 through a redox mechanism. J. Biol. Chem. 2000, 275, 8487-8491. [CrossRef] [PubMed] 
156. Park, H.S.; Park, E.; Kim, M.S.; Ahn, K.; Kim, I.Y.; Choi, E.J. Selenite inhibits the c-Jun N-terminal kinase/stress-activated protein kinase (JNK/SAPK) through a thiol redox mechanism. J. Biol. Chem. 2000, 275, 2527-2531. [CrossRef]

157. Liou, G.-Y.; Storz, P. Reactive oxygen species in cancer. Free Radic. Res. 2010, 44, 479-496. [CrossRef]

158. Oberley, L.W.; Buettner, G.R. Role of superoxide dismutase in cancer: A review. Cancer Res. 1979, 39, 1141-1149.

159. Buettner, G.R. Superoxide dismutase in redox biology: The roles of superoxide and hydrogen peroxide. Anticancer. Agents Med. Chem. 2011, 11, 341-346. [CrossRef]

160. Aykin-Burns, N.; Ahmad, I.M.; Zhu, Y.; Oberley, L.W.; Spitz, D.R. Increased levels of superoxide and H2O2 mediate the differential susceptibility of cancer cells versus normal cells to glucose deprivation. Biochem. J. 2009, 418, 29-37. [CrossRef]

161. Lu, J.; Kaeck, M.; Jiang, C.; Wilson, A.C.; Thompson, H.J. Selenite induction of DNA strand breaks and apoptosis in mouse leukemic L1210 cells. Biochem. Pharmacol. 1994, 47, 1531-1535. [CrossRef]

162. Yan, L.; Frenkel, G.D. Inhibition of Cell Attachment by Selenite. Cancer Res. 1992, 52, 5803.

163. Garberg, P.; Stahl, A.; Warholm, M.; Hogberg, J. Studies of the role of DNA fragmentation in selenium toxicity. Biochem. Pharmacol. 1988, 37, 3401-3406. [CrossRef]

164. Peyroche, G.; Saveanu, C.; Dauplais, M.; Lazard, M.; Beuneu, F.; Decourty, L.; Malabat, C.; Jacquier, A.; Blanquet, S.; Plateau, P. Sodium Selenide Toxicity Is Mediated by O2-Dependent DNA Breaks. PLoS ONE 2012, 7, e36343. [CrossRef] [PubMed]

165. Wycherly, B.J.; Moak, M.A.; Christensen, M.J. High dietary intake of sodium selenite induces oxidative DNA damage in rat liver. Nutr. Cancer 2004, 48, 78-83. [CrossRef] [PubMed]

166. Wallenberg, M.; Misra, S.; Wasik, A.M.; Marzano, C.; Bjornstedt, M.; Gandin, V.; Fernandes, A.P. Selenium induces a multi-targeted cell death process in addition to ROS formation. J. Cell. Mol. Med. 2014, 18, 671-684. [CrossRef]

167. Brigelius-Flohé, R.; Müller, M.; Lippmann, D.; Kipp, A.P. The Yin and Yang of Nrf2-Regulated Selenoproteins in Carcinogenesis. Int. J. Cell Biol. 2012, 2012, 1-8. [CrossRef]

168. Motohashi, H.; Yamamoto, M. Nrf2-Keap1 defines a physiologically important stress response mechanism. Trends Mol. Med. 2004, 10, 549-557. [CrossRef]

169. Johnson, J.A.; Johnson, D.A.; Kraft, A.D.; Calkins, M.J.; Jakel, R.J.; Vargas, M.R.; Chen, P.C. The Nrf2-ARE pathway: An indicator and modulator of oxidative stress in neurodegeneration. Ann. N. Y. Acad. Sci. 2008, 1147, 61-69. [CrossRef]

170. Itoh, K.; Chiba, T.; Takahashi, S.; Ishii, T.; Igarashi, K.; Katoh, Y.; Oyake, T.; Hayashi, N.; Satoh, K.; Hatayama, I.; et al. An Nrf2/Small maf heterodimer mediates the induction of phase II detoxifying enzyme genes through antioxidant response elements. Biochem. Biophys. Res. Commun. 1997, 236, 313-322. [CrossRef]

171. Raghunath, A.; Sundarraj, K.; Nagarajan, R.; Arfuso, F.; Bian, J.; Kumar, A.P.; Sethi, G.; Perumal, E. Antioxidant response elements: Discovery, classes, regulation and potential applications. Redox Biol. 2018, 17, 297-314. [CrossRef]

172. Brigelius-Flohe, R.; Banning, A. Part of the series: From dietary antioxidants to regulators in cellular signaling and gene regulation. Sulforaphane and selenium, partners in adaptive response and prevention of cancer. Free Radic. Res. 2006, 40, 775-787. [CrossRef] [PubMed]

173. Liu, T.; Zeng, L.; Jiang, W.; Fu, Y.; Zheng, W.; Chen, T. Rational design of cancer-targeted selenium nanoparticles to antagonize multidrug resistance in cancer cells. Nanomed. Nanotechnol. Biol. Med. 2015, 11, 947-958. [CrossRef] [PubMed]

174. Hadrup, N.; Loeschner, K.; Mandrup, K.; Ravn-Haren, G.; Frandsen, H.L.; Larsen, E.H.; Lam, H.R.; Mortensen, A. Subacute oral toxicity investigation of selenium nanoparticles and selenite in rats. Drug Chem. Toxicol. 2019, 42, 76-83. [CrossRef] [PubMed]

175. Muecke, R.; Micke, O.; Schomburg, L.; Glatzel, M.; Reichl, B.; Kisters, K.; Schaefer, U.; Huebner, J.; Eich, H.T.; Fakhrian, K.; et al. Multicenter, phase III trial comparing selenium supplementation with observation in gynecologic radiation oncology: Follow-up analysis of the survival data 6 years after cessation of randomization. Integr. Cancer Ther. 2014, 13, 463-467. [CrossRef]

176. Muecke, R.; Schomburg, L.; Glatzel, M.; Berndt-Skorka, R.; Baaske, D.; Reichl, B.; Buentzel, J.; Kundt, G.; Prott, F.J.; Devries, A.; et al. Multicenter, phase 3 trial comparing selenium supplementation with observation in gynecologic radiation oncology. Int. J. Radiat. Oncol. Biol. Phys. 2010, 78, 828-835. [CrossRef] 
177. Garje, R.; An, J.; Sanchez, K.; Greco, A.; Stolwijk, J.; Devor, E.; Rustum, Y.; Zakharia, Y. Current landscape and the potential role of hypoxia-inducible factors and selenium in clear cell renal cell carcinoma treatment. Int. J. Mol. Sci. 2018, 19, 3834. [CrossRef]

178. Garje, R.; Brown, J.A.; Nepple, K.G.; Dahmoush, L.; Bellizzi, A.; Bonner, J.; Mott, S.L.; Zamba, G.; Laux, D.E.; Milhem, M.M.; et al. Preliminary results of phase I clinical trial of high doses of seleno-L-methionine (SLM) in sequential combination with axitinib in previously treated and relapsed clear cell renal cell carcinoma (ccRCC) patients. J. Clin. Oncol. 2019, 37, 660. [CrossRef]

179. Brodin, O.; Eksborg, S.; Wallenberg, M.; Asker-Hagelberg, C.; Larsen, E.H.; Mohlkert, D.; Lenneby-Helleday, C.; Jacobsson, H.; Linder, S.; Misra, S.; et al. Pharmacokinetics and toxicity of sodium selenite in the treatment of patients with carcinoma in a phase I clinical trial: The secar study. Nutrients 2015, 7, 4978-4994. [CrossRef]

180. Bhattacharya, A.; Seshadri, M.; Oven, S.D.; Tóth, K.; Vaughan, M.M.; Rustum, Y.M. Tumor vascular maturation and improved drug delivery induced by methylselenocysteine leads to therapeutic synergy with anticancer drugs. Clin. Cancer Res. 2008, 14, 3926. [CrossRef]

181. Bhattacharya, A.; Tóth, K.; Sen, A.; Seshadri, M.; Cao, S.; Durrani, F.A.; Faber, E.; Repasky, E.A.; Rustum, Y.M. Inhibition of colon cancer growth by methylselenocysteine-induced angiogenic chemomodulation is influenced by histologic characteristics of the tumor. Clin. Colorectal Cancer 2009, 8, 155-162. [CrossRef]

182. Cao, S.; Durrani, F.A.; Rustum, Y.M. Selective modulation of the therapeutic efficacy of anticancer drugs by selenium containing compounds against human tumor xenografts. Clin. Cancer Res. 2004, 10, 2561-2569. [CrossRef] [PubMed]

183. Toth, K.; Chintala, S.; Rustum, Y.M. Constitutive expression of HIF-alpha plays a major role in generation of clear-cell phenotype in human primary and metastatic renal carcinoma. Appl. Immunohistochem. Mol. Morphol. 2014, 22, 642-647. [CrossRef]

184. Chintala, S.; Najrana, T.; Toth, K.; Cao, S.; Durrani, F.A.; Pili, R.; Rustum, Y.M. Prolyl hydroxylase 2 dependent and Von-Hippel-Lindau independent degradation of Hypoxia-inducible factor 1 and 2 alpha by selenium in clear cell renal cell carcinoma leads to tumor growth inhibition. BMC Cancer 2012, 12, 293. [CrossRef] [PubMed]

185. Chintala, S.; Toth, K.; Cao, S.; Durrani, F.A.; Vaughan, M.M.; Jensen, R.L.; Rustum, Y.M. Se-methylselenocysteine sensitizes hypoxic tumor cells to irinotecan by targeting hypoxia-inducible factor 1alpha. Cancer Chemother. Pharm. 2010, 66, 899-911. [CrossRef] [PubMed]

186. Cho, H.; Du, X.; Rizzi, J.P.; Liberzon, E.; Chakraborty, A.A.; Gao, W.; Carvo, I.; Signoretti, S.; Bruick, R.K.; Josey, J.A.; et al. On-target efficacy of a HIF-2alpha antagonist in preclinical kidney cancer models. Nature 2016, 539, 107-111. [CrossRef] [PubMed]

187. Chen, W.; Hill, H.; Christie, A.; Kim, M.S.; Holloman, E.; Pavia-Jimenez, A.; Homayoun, F.; Ma, Y.; Patel, N.; Yell, P.; et al. Targeting renal cell carcinoma with a HIF-2 antagonist. Nature 2016, 539, 112-117. [CrossRef] [PubMed]

188. Escudier, B.; Porta, C.; Schmidinger, M.; Rioux-Leclercq, N.; Bex, A.; Khoo, V.; Grunwald, V.; Gillessen, S.; Horwich, A. Renal cell carcinoma: ESMO Clinical Practice Guidelines for diagnosis, treatment and follow-updagger. Ann. Oncol. 2019, 30, 706-720. [CrossRef]

189. Burk, R.F.; Hill, K.E.; Motley, A.K. Plasma selenium in specific and non-specific forms. BioFactors 2001, 14, 107-114. [CrossRef]

190. Hondal, R.J.; Motley, A.K.; Hill, K.E.; Burk, R.F. Failure of selenomethionine residues in albumin and immunoglobulin G to protect against peroxynitrite. Arch. Biochem. Biophys. 1999, 371, 29-34. [CrossRef]

191. Hu, X.; Chandler, J.D.; Orr, M.L.; Hao, L.; Liu, K.; Uppal, K.; Go, Y.-M.; Jones, D.P. Selenium supplementation alters hepatic energy and fatty acid metabolism in mice. J. Nutr. 2018, 148, 675-684. [CrossRef]

192. Berntsson, R.P.; Alia Oktaviani, N.; Fusetti, F.; Thunnissen, A.M.; Poolman, B.; Slotboom, D.J. Selenomethionine incorporation in proteins expressed in Lactococcus lactis. Protein Sci. 2009, 18, 1121-1127. [CrossRef] [PubMed]

193. Nair, D.; Radestad, E.; Khalkar, P.; Diaz-Argelich, N.; Schroder, A.; Klynning, C.; Ungerstedt, J.; Uhlin, M.; Fernandes, A.P. Methylseleninic acid sensitizes ovarian cancer cells to T-Cell mediated killing by decreasing PDL1 and VEGF levels. Front. Oncol. 2018, 8, 407. [CrossRef] [PubMed] 
194. Hu, H.; Jiang, C.; Ip, C.; Rustum, Y.M.; Lu, J. Methylseleninic acid potentiates apoptosis induced by chemotherapeutic drugs in androgen-independent prostate cancer cells. Clin. Cancer Res. 2005, 11, 2379-2388. [CrossRef] [PubMed]

195. Mas, A.; Sarkar, B. Role of glutathione in selenite binding by human plasma. Biol. Trace Elem. Res. 1989, 20, 95-104. [CrossRef] [PubMed]

196. Bothwell, I.R.; Islam, K.; Chen, Y.; Zheng, W.; Blum, G.; Deng, H.; Luo, M. Se-Adenosyl-l-selenomethionine cofactor analogue as a reporter of protein methylation. J. Am. Chem. Soc. 2012, 134, 14905-14912. [CrossRef] [PubMed]

197. Azad, G.K.; Tomar, R.S. Ebselen, a promising antioxidant drug: Mechanisms of action and targets of biological pathways. Mol. Biol. Rep. 2014, 41, 4865-4879. [CrossRef]

198. Schewe, T. Molecular actions of ebselen-an antiinflammatory antioxidant. Gen. Pharmacol. 1995, 26, 1153-1169. [CrossRef]

199. Caeran Bueno, D.; Meinerz, D.F.; Allebrandt, J.; Waczuk, E.P.; Dos Santos, D.B.; Mariano, D.O.; Rocha, J.B. Cytotoxicity and genotoxicity evaluation of organochalcogens in human leucocytes: A comparative study between ebselen, diphenyl diselenide, and diphenyl ditelluride. Biomed. Res. Int. 2013, 2013, 537279. [CrossRef] [PubMed]

200. Tavadyan, L.A.; Manukyan, Z.H.; Harutyunyan, L.H.; Musayelyan, M.V.; Sahakyan, A.D.; Tonikyan, H.G. antioxidant properties of selenophene, thiophene and their aminocarbonitrile derivatives. Antioxidants (Basel) 2017, 6. [CrossRef] [PubMed]

201. Juang, S.H.; Lung, C.C.; Hsu, P.C.; Hsu, K.S.; Li, Y.C.; Hong, P.C.; Shiah, H.S.; Kuo, C.C.; Huang, C.W.; Wang, Y.C.; et al. D-501036, a novel selenophene-based triheterocycle derivative, exhibits potent in vitro and in vivo antitumoral activity which involves DNA damage and ataxia telangiectasia-mutated nuclear protein kinase activation. Mol. Cancer Ther. 2007, 6, 193-202. [CrossRef]

202. Fairweather-Tait, S.J.; Bao, Y.; Broadley, M.R.; Collings, R.; Ford, D.; Hesketh, J.E.; Hurst, R. Selenium in human health and disease. Antioxid. Redox Signal. 2011, 14, 1337-1383. [CrossRef] [PubMed]

203. Schomburg, L.; Orho-Melander, M.; Struck, J.; Bergmann, A.; Melander, O. Selenoprotein-P deficiency predicts cardiovascular disease and death. Nutrients 2019, 11. [CrossRef] [PubMed]

204. Bomer, N.; Grote Beverborg, N.; Hoes, M.F.; Streng, K.W.; Vermeer, M.; Dokter, M.M.; J, I.J.; Anker, S.D.; Cleland, J.G.F.; Hillege, H.L.; et al. Selenium and outcome in heart failure. Eur. J. Heart Fail. 2019. [CrossRef] [PubMed]

205. Muecke, R.; Micke, O.; Schomburg, L.; Buentzel, J.; Kisters, K.; Adamietz, I.A. Selenium in radiation Oncology-15 years of experiences in Germany. Nutrients 2018, 10. [CrossRef] [PubMed] 